\title{
Does Industry Size Matter? Revisiting European Mutual Fund Performance.
}

\author{
Roger Otten \\ Maastricht University and Philips Pension Fund
}

Kilian Thevissen

Philips Pension Fund

\begin{abstract}
This paper revisits the performance of European mutual funds using a more recent and extensive survivorship bias free database of 16,055 equity funds over the 1992-2006 period. Earlier evidence by Otten \& Bams (2002) pointed to an exceptional position of European mutual funds. In sharp contrast to for instance the United States, the authors documented that European mutual funds were able to add value, based on their positive alphas. Otten \& Bams (2002) contributed that ability to the relative small size of the European mutual fund industry compared to the total stock market (around 13\% in 1998). By 2005 this size has almost doubled to $25 \%$. The main motivation for our study is to examine whether this had an impact on the ability of European mutual funds to beat the market. Our main results are four-fold. First, we indeed find that European mutual funds deliver significantly negative 4-factor Carhart alpha's during this more recent period. The larger current size of the European mutual fund industry makes it more difficult for managers to add value. These results are now more in line with earlier results for US funds. Second, passive funds perform even worse than active funds, leaving us with a puzzle. It might be that passive funds are not pure indextrackers but active funds in disguise. Third, adding back TER's and loads make most alphas insignificantly different from zero. Which means that European fund managers are able to follow the market but charge investors too much for this. Fourth, we find strong persistence in performance in all investigated countries over both 6 and 12 month holding periods.
\end{abstract}

JEL classification: G12, G20, G23,

Keywords: Mutual funds, Performance evaluation, Portfolio management, European mutual fund industry

\section{Acknowledgements}

We would like to thank Jan Losen for research assistance. All remaining errors are the sole responsibility of the authors. The views expressed in this paper are not necessarily shared by Philips Pension Fund.

Corresponding author: r.otten@maastrichtuniversity.nl 


\section{Introduction}

This paper revisits the performance of European mutual funds. More specifically we reexamine earlier evidence documented by Otten \& Bams (2002). Their study found that European mutual funds were able to add value for their investors, based on positive Carhart 4factor alphas. The main reason for this outperformance as put forward in Otten \& Bams (2002) relates to the small market importance of the European mutual fund industry as compared to the total stock market capitalisation. By the end of their sample period (1998) the European mutual fund industry presented a stake of $13 \%$ of the total market capitalisation. This put European managers in a better position to outsmart their local market. At that time the US industry represented a stake close to $25 \%$. This large stake of the US industry partly explains the general finding in the literature that US mutual funds are not able to beat the market after fees.

This study aims at re-visiting European mutual funds performance during a more recent period. Our main hypothesis is that the tremendous growth of the European mutual fund industry since 1998 might have an influence on the ability of managers to add value for investors. By the end of 2005 the European industry accounted for $25 \%$ of total assets in their local stock market. Doubling their market importance might limit opportunities to beat the market.

We employ a very rich database of 16,055 equity mutual funds from 5 countries, France, Germany, Italy, Spain and the United Kingdom. Our sample period ranges from 1992-2006, which enables us to test the hypothesis that the strong growth of the European industry since 1998 might have a negative impact on the ability of fund managers to produce positive alphas. Using a conditional 4-factor Carhart model we measure performance and test for persistence. In addition to that we study the performance of active versus passive mutual funds and the influence of fund characteristics on risk-adjusted performance.

The remainder of this study is organized as follows. Section 2 gives an overview of the historical development of the European mutual fund market. In Section 3 the employed datasets and benchmarks are described. Section 4 provides our main results, while section 5 summarizes the most important findings. 


\section{The European Mutual Fund Market}

From 1995 to 2005 the size of the European market more than quadrupled from $€ 1,190$ billion to $€ 5,182$ billion, while growing on average by $15.9 \%$ p.a.. Most of this asset growth can be attributed to the average growth rate of $24.4 \%$ p.a. during the period from 1995 to 1999 , whereas due to the overall market downturn the average growth slowed down to $7.9 \%$ p.a. from 2000 to 2005 (EFAMA, 2006). Because of their immense size, the mutual fund markets are a decisive part of the European financial system and the mutual fund industry has a high economic importance. As shown in Figure 1, the European market accounts for $33 \%$ of the global mutual fund assets, while the US market is still the most important one with a share of $49 \%$. Other global regions only contribute minor parts to the global market's size.

\section{Insert Figure 1 about here}

\section{Insert Figure 2 about here}

The overall European mutual fund market can be split up into the national markets of the numerous European countries. Yet about $50 \%$ of the total mutual fund assets are domiciled in the five countries with the highest GDP, namely France, Germany, Italy, Spain, and the United Kingdom - which are also the focus of this study. Figure 2 displays the contributions of the individual national markets to the overall size of the European market. At first sight the relatively high shares of Ireland and especially Luxembourg stand out since their GDP level is quite low when compared to countries like France or the UK. However, Ireland and Luxembourg have emerged as distribution and administration centers for large mutual fund management companies operating in the European market. This development can be traced back to low tax rates, relatively liberal and flexible regulatory authorities, and potential economies of scale which can arise when concentrating the fund domicile in one country. Consequently, most of the funds domiciled in these countries are sold to investors in other national European markets and are therefore also considered in this study. Table 1 presents the composition and characteristics of the global mutual fund market and its constituents. Clearly, the overall American market is in all respects dominated by the United States. This in contrast to the overall European market, where no single national market accounts for more than one third of the total assets under management. 
It appears that the equity segment, which represents the focus of our study, is the largest segment in all regional or national markets, while the bond, balanced, and money market segments are most often significantly smaller. A further decisive difference between the European and US markets is the average fund size. On average US funds have about €924 billion of assets under management, as opposed to their European counterparts with only $€ 166$ billion. This immense difference can possibly become critical when it comes to the exploitation of economies of scale.

\section{Insert Table 1 about here}

\section{Insert Table 2 about here}

Besides the lower average fund size and total net asset values also the importance of the European equity mutual fund markets in their respective equity markets has in the past been significantly lower than the one of the US counterpart. Table 2 illustrates the sizes of the equity mutual fund markets as a percentage of the total stock market capitalization in the respective countries or region, based on the funds' domiciles. The range of funds covered here does not only include funds with a domestic, but also funds with a European and global investment focus. Since most of the funds domiciled in Luxembourg or Ireland are sold in other national European markets, their annual asset values are allocated to the other European countries.

In comparison to the US, the importance of the equity mutual fund industry has been remarkably lower in Europe during the 1990s, however over time the fund market's importance for both the financial markets and the overall economies has increased significantly across Europe. During 1995 the relative size of the equity fund industries in the five European countries under investigation amounted to only $11 \%$, but this percentage constantly grew up to $25 \%$ in 2005 . While the size and importance of the US fund industry increased at the same time as well, the corresponding figures of the European counterpart significantly caught up over the last decade with the difference in 2005 amounting to only 4\%. Therefore today, changes in the state of the European mutual fund industry can have farreaching consequences for all entities being directly or indirectly connected to and dependent on its operations, especially investors and the entities in which the industry is invested in. 


\section{Data}

\subsection{Mutual Fund data}

In order to analyze the performance characteristics of European mutual funds, two datasets are employed. The first dataset has been constructed by Lipper Inc. and contains monthly returns on 17,384 equity mutual funds listed in France, Germany, Italy, Spain, and the UK, covering the period from January 1992 to March 2006. Originally the returns are net of fees and given in different currencies depending on their individual investment foci. In order to make them comparable a conversion into Euro denominated returns is performed by using exchange rates obtained from DataStream. This time series dataset includes almost all equity funds which were available in the five countries during the time period at hand, thus live as well as liquidated and merged funds are taken into account. Consequently, the dataset is free of survivorship bias and a comprehensive representation of the five national equity mutual fund markets. For the analysis at hand only funds with at least 12 months of data are taken into account, resulting in a time series sample of 16,055 equity mutual funds. The comprehensive character of the dataset enables this study to draw robust conclusions about the performance characteristics of equity mutual funds in Europe.

Table 3 shows the summary statistics for the first dataset. All returns stated are net of fees and calculated over the full sample period as equally weighted averages. Funds listed in a certain country are subdivided into the categories domestic-, European-, and global investment focus. Therefore, the overall sample is split up into 15 subsamples which will be investigated independently during the course of this study. Although the dataset offers even more precise information on the funds' specific investment foci, this broad classification is chosen in order to restrict the number of benchmarks employed in the performance models.

Throughout all countries funds with a domestic or European investment focus have higher average returns than their globally focused counterparts. This result is not surprising since European investment managers can be expected to be more familiar with the financial markets and economic conditions within Europe, thus enabling them to reap higher returns on investments in the European markets. Furthermore, the returns on funds focused on the domestic and the European markets have lower standard deviations, which might indicate that those funds' managers are better able to predict the actual returns on their investments in order to achieve a more constant fund return over time. Table 3 also outlines the importance of the survivorship bias free character of the time series dataset. Several studies like those by 
Brown, Goetzmann, Ibbotson, and Ross (1992) or Malkiel (1995) have shown that a survivorship biased dataset can lead to significantly different results than a survivorship bias free dataset, since the former one does not include funds which have been liquidated or merged during the time period covered. Because these funds are likely to underperform their benchmarks, their exclusion from the dataset leads to an overestimation of the true average returns. When considering only the live funds in March 2006, the average returns of the subsamples are up to $0.4 \%$ higher than those calculated when taking the dead funds into account as well.

\section{Insert Table 3 about here}

The second dataset has been obtained from Lipper-Fitzrovia and consists of annual crosssectional information on 15,975 equity funds listed in France, Germany, Italy, Spain, and the UK, covering the period from 1991 to 2005 . For each fund the cross-sectional information includes about 70 characteristics like age, fees or fund size. Absolute monetary amounts are stated in the respective reporting currency of the funds and are therefore converted into Euros.

Figure 3 displays the development of the funds' average $\mathrm{TSC}^{1}, \mathrm{TER}^{2}$ and load charges ${ }^{3}$ over the time period covered by the second dataset individually for each of the five countries. Apparently, all three cost measures decline notably for all countries between 1991 and 2005 . This in line with the intuitive expectations since the European mutual fund market has experienced tremendous growth rates during the 1990s. A larger size in terms of net asset values implies a better exploitation of economies of scale which in turn leads to decreasing cost ratios. Moreover, funds in the UK exhibit the lowest expense and load charges of all five countries. This might be due to the larger size of the UK fund market when compared to its European peers.

Finally, the time series and the cross-sectional datasets are then matched by the funds' ISIN numbers and a comprehensive dataset containing both returns and fund characteristics for 7,681 funds is created.

\section{Insert Figure 3 about here}

\footnotetext{
${ }^{1}$ Total Shareholder Cost

${ }^{2}$ Total Expense Ratio

${ }^{3}$ Load charges include both initial and redemption loads
} 


\subsection{Benchmarks}

The summary statistics of the benchmark returns and their cross correlations are presented in Table 4. All risk-adjusted performance estimation models require a market return benchmark as an essential input. Market benchmarks are calculated for the stock markets in each of the five countries under investigation, for the overall European and for the overall global stock market. The calculations are based on the Thomson Financial Worldscope universe, which includes about $95 \%$ of the global market capitalization and covers about 50,000 stocks. The excess returns are calculated by subtracting the one-month interbank rate of the respective country. According to Table 4, most fund categories exhibit lower total returns than their respective market benchmarks, consequently on average equity mutual funds seem to underperform the market, at least in terms of total returns.

While the CAPM only requires the market return, the Fama French 3-factor model and the Carhart 4-factor model necessitate further benchmarks, namely SMB denoting the return difference between small- and large-cap stocks, HML denoting the return difference between value (high-book-to-market ratio) and growth (low-book-to-market ratio) stocks, and MOM denoting the return difference between past winner and past looser stocks. These benchmarks are calculated on a monthly basis by using factor mimicking portfolios. For the estimation of the SMB factors all stocks in the financial market of interest are ranked according to their size. Thereafter, two portfolios are formed, the first including the $20 \%$ of stocks with the highest market capitalization and the second including the $20 \%$ of stocks with the lowest capitalization. The SMB factor is then calculated as the difference between the returns on the two portfolios over the upcoming month. This procedure is applied to each month in the sample period in order to yield a rolling SMB benchmark.

The other two benchmarks are estimated in a similar fashion. For the determination of the HML benchmarks the stocks in the market of interest are ranked with respect to their book-tomarket ratios. Each month the top 30\% and bottom 30\% stocks the assigned to separate portfolios and the return difference between these portfolios during the upcoming month is then used as the respective month's HML factor. The MOM factor is obtained by ranking the stocks on the prior 12 month returns and calculating the return difference between the top $30 \%$ and bottom $30 \%$ of market capitalization during the upcoming month.

\section{Insert Table 4 about here}


In line with the findings of Banz (1981), the SMB factor premium of the domestic and European equity markets are nearly always positive, thus indicating that small-cap stocks have performed better in terms of total returns. However, in the global equity markets largecap stocks have apparently performed better since the SMB factor is significantly negative. More consistent values are found with respect to the HML factor premiums, which are all positive and thus in line with the findings of Basu (1983). A momentum investment strategy in the spirit of Jegadeesh and Titman (1993) seems to be profitable in the European and the global equity markets due to the positive factor premiums. Yet only the domestic markets of Italy and the UK exhibit positive values, while all other three nations display negative ones, thus indicating that there is momentum reversal. This is contrary to Rouwenhorst (1998), who finds positive momentum factor premiums in all European equity markets. Rouwenhorst however covers the period from 1980 to 1995, which is almost non-overlapping with the period at hand. Finally, the low cross correlations presented in Table 4 suggest that multicollinearity does not have a major impact on the estimated factor loadings of the performance models.

\section{Results}

\subsection{Risk-adjusted performance}

The most basic model used to measure performance is the 1-factor CAPM model that reads as follows;

$R_{i t}-R_{f t}=\alpha_{i}+\left(R_{M t}-R_{f t}\right) \beta_{i M}+\varepsilon_{i t}$

where $R_{i t}$ is the return on fund $\mathrm{i}$ in month $\mathrm{t}, R_{f t}$ the risk-free rate in month $\mathrm{t}, R_{M t}$ the return on the relevant market benchmark in month $\mathrm{t}, \alpha_{i}$ the risk-adjusted abnormal on fund $\mathrm{i}, \beta_{i M}$ the market beta of fund i, and $\varepsilon_{i t}$ an error term.

Although the use of the CAPM is still very common, over the last decades researchers have come up with adjustments or even new models for estimating risk-adjusted returns. In this so called "Is beta dead?"-debate very different opinions on possible mistakes and flaws inherent to the CAPM are brought forward. For example Banz (1981) and Basu (1983) question the validity of the CAPM because they find a stock's returns to be related to its market capitalization and book-to-market (BM) ratio. Banz (1981) shows stocks with a high market 
capitalization to earn lower returns than predicted by the CAPM, while the reverse holds for low market capitalization stocks. Besides this, Basu (1983) documents a positive relation between an underlying stock's book-to-market ratio and the Jensen alpha. Therefore, the CAPM tends to underestimate the returns on high book-to-market ratio stocks and to overestimate those for low book-to-market ratio ones.

In line with these results Fama and French (1992) find the inclusion of a book-to-market and a capitalization factor to cause an increase in the predictive power of an asset pricing model, while at the same time the market beta gets almost insignificant. Based on this they formulate a new three factor model:

$R_{i t}-R_{f t}=\alpha_{i}+\left(R_{M t}-R_{f t}\right) \beta_{i M}+S M B_{t} \beta_{i S M B}+H M L_{t} \beta_{i H M L}+\varepsilon_{i t}$

where SMB denotes the return difference between a small-cap and a large-cap stock portfolio, HML denotes the return difference between a high book-to-market and a low book-to-market stock portfolio, while $\beta_{S M B}$ and $\beta_{H M L}$ represent fund i's sensitivities to these two risk factors. The authors $(1993,1996,1998)$ show this model to significantly outperform the CAPM in explaining historical stock returns in terms of the regressions' adjusted $\mathrm{R}^{2}$ values. Therefore, it gives a better explanation of the return variation among stocks or funds.

Other authors like Jegadeesh and Titman (1993) and especially Carhart (1997) find an additional factor which also tends to have explanatory power with respect to stock returns, the momentum factor. The researchers observe that stocks with extraordinary high returns in the past 12 months tend to exhibit the same characteristic over the upcoming 12 months as well. Carhart (1997) therefore extends the Fama French model by a stock momentum factor:

$R_{i t}-R_{f t}=\alpha_{i}+\left(R_{M t}-R_{f t}\right) \beta_{i M}+S M B_{t} \beta_{i S M B}+H M L_{t} \beta_{i H M L}+M O M_{t} \beta_{i M O M}+\varepsilon_{i t}$

where MOM denotes the return difference between a portfolio of past winner and a portfolio of past loser stocks, while $\beta_{\text {імом }}$ is the corresponding sensitivity of fund i. Carhart (1997) however leaves it open to the reader whether to interpret his 4-factor model as a riskadjustment or performance attribution model. In each case the model delivers risk-adjusted returns which make the performance of funds comparable on a cross-sectional basis.

Since the upcoming analysis of performance characteristics will be based primarily on only one of those three performance models, their explanatory power is compared in order to choose the superior one. For this purpose models (1), (2), and (3) are applied to equally 
weighted portfolios containing all funds of a certain country and investment focus over the full time series sample period from January 1992 to March 2006. Consequently 15 regressions are conducted, while for each one the respective benchmarks are used. For all regressions reported in this thesis standards errors are autocorrelation and Newey-West heteroskedasticity consistent.

Table 5 clearly demonstrates the dominance of multi-factor models Fama French and Carhart) over the 1-factor CAPM model, according to the reported $\log 1$ ratios. An examination of reported multi-factor alphas clearly point to the inability of European mutual funds to beat their benchmark. All reported alpha's are negative (with Italy domestic as the only exception) with 11 out of 14 to be significantly negative. This in sharp contrast to Otten \& Bams (2002) who document multi-factor alphas to mostly positive, although statistically indifferent from zero. As indicated before, Otten \& Bams (2002) argue that the low market importance of European mutual funds puts European fund managers in a better position to add value. Since the end of the Otten \& Bams (2002) sample period, 1998, the relative importance of the European mutual industry almost doubled (from 13\% to 25\%). This stake is similar to the stake the US mutual fund industry has in their local market. Based on extensive evidence on US Mutual fund performance we know that US funds deliver significantly negative alphas. This provides an intuitive explanation as to why European mutual funds now perform in line with their US counterparts. As a result of the increasing size of the European industry as a percentage of the total stock market capitalisation, it becomes ever more difficult for fund managers to outsmart the market and add value for investors after fees are deducted.

\section{Insert Table 5 about here}

\subsection{Conditional Performance Measurement}

The previous results are based on unconditional multi-factor models that estimate average alphas by employing coefficient estimates that are constant over the entire period of investigation. However, managers may in fact trade in response to publicly available information. In this case they employ dynamic strategies, implying varying coefficients of the Carhart 4-factor model over time. Here the estimates of the standard 4-factor model are highly unreliable. In order to prevent this flaw Chan and Knez (1996) and Ferson and Schadt (1996) propose the use of a conditional model, allowing for changing regression coefficients over the period of investigation. 
For the purpose of illustration consider the case of the single factor CAPM and $\boldsymbol{Z}_{\boldsymbol{t}-\mathbf{1}}$, which denotes a vector of lagged and pre-determined instruments like the risk-free rate. If the variation in the market beta of a certain fund can be explained by a linear relationship to the pre-determined instruments, the actual market beta at time t equals to $\beta_{i t}=\beta_{i M}+\boldsymbol{B}_{i}^{\prime} \boldsymbol{Z}_{t-\mathbf{1}}$, where $\boldsymbol{B}_{i}^{\prime}$ is a vector of response coefficients to the vector of pre-determined instruments $\boldsymbol{Z}_{\boldsymbol{t}-\mathbf{1}}$. Thus, the CAPM can be extended to the following form in order to take the conditional market beta variation into account:

$R_{i t}-R_{f t}=\alpha_{i}+\beta_{i M}\left(R_{M t}-R_{f t}\right)+\boldsymbol{B}_{i}^{\prime} \boldsymbol{Z}_{t-\mathbf{1}}\left(R_{M t}-R_{f t}\right)+\varepsilon_{i}$

This equation is easily extendable in order to take the 4-factors of the Carhart model into account, therefore representing the conditional Carhart 4-factor model. In this study the following pre-determined instruments are used since they are publicly available and have already been found to have explanatory power with respect to stock returns:

- the risk-free rate as represented by the one month interbank rates

- the dividend yield on the market index

- the slope of the term structure as represented by the difference between the yields on 10 year and 1 year government bonds

- the quality spread, denoting the difference in yield on AAA-rated and BAA-rated corporate bonds

The upcoming analysis will employ individual one month interbank rates, dividend yields, and term structure slopes for the five countries under investigation, while a global quality spread will be applied to all fund categories.

\section{Insert Table 6 about here}

In order to arrive at Table 6 the analysis of Table 5 is repeated by estimating the unconditional and conditional Carhart 4-factor models. In order to examine the additional explanatory power of the conditional model Wald tests are conducted. As shown in Table 6, the alpha values do not seem to be constant because the Wald test p-values are most of the times below 5\%. The results of the conditional model confirm and even strengthen our previous findings, all alphas are negative, and the majority of them statistically different from zero. As indicated by the 
higher adjusted $\mathrm{R}^{2}$ value, the conditional model is superior in explaining the returns on all funds.

\subsection{Active vs. Passive Funds}

The analysis performed so far included all funds covered in the Lipper database. This includes funds that are classified as index-tracking/passive. As this might provide a distorted picture we re-run our analysis while sorting funds into active and passive portfolios. The results of this are summarised in Table 7. This provides an unexpected result. Active funds outperform passive funds in many cases, as indicated by the positive active-passive spread return. On a stand-alone basis, passive funds underperform their benchmarks in all countries and investment foci. The underperformance is both economically and statistically significant in many cases. This might indicate that European passive funds are not entirely passive investors. This is supported by their market beta's which in most cases are far from 1 . European investors therefore cannot turn to passive funds covered in this analysis as an alternative to active funds.

\section{Insert Table 7 about here}

\subsection{Before and after fee performance}

We have so far considered mutual fund returns net of costs. This means management fees were already deducted from the fund's return. ${ }^{4}$ To judge the abilities of mutual fund managers to follow the market we now add back fees to the monthly excess returns and re-run our analysis. First we add back load fees (assuming a 3 year holding period), after that we add back TER's. Table 8 presents the results of this analysis. Adding back loads and TER's makes most alphas to become positive, however insignificantly different from zero. This again in sharp contrast to previous work on European mutual funds by Otten \& Bams (2002). In their study adding back fees leads to statistically positive alphas for 4 out of 5 countries. Our results however are more in line with evidence on US markets, after adding back fees alphas become insignificantly different from zero. This means managers are able to follow the market but charge too high fees to investors to deliver outperformance.

\section{Insert Table 8 about here}

\footnotetext{
$\overline{{ }^{4} \text { Loads however are not considered. }}$
} 


\subsection{The influence of fund characteristics on risk-adjusted performance}

Mutual funds can be characterized on a variety of attributes. However, their impact on the risk-adjusted abnormal returns is often not straight forward. Popular examples are the fees and loads charged to investors. Mutual fund companies often claim that they are able to recoup higher fees and expenses by higher gross returns, yet this claim is more than questionable in face of the significant average underperformance of actively managed funds. In order to evaluate the effect of several characteristics on the risk-adjusted performance, all mutual funds of the merged dataset which were alive during 2004 are investigated with respect to this purpose. Here the year 2004 is chosen since it contains the highest number of funds being active. In a first step the unconditional Carhart model is applied to each fund on an individual basis for the full sample period. The funds' individual Carhart model alphas are then regressed against its various characteristics in three different regression sets. The model of the first regression set includes the TSC as a measure for the funds' expenses and its loads. In the second regression set this TSC is split up into the TER and the initial and redemption loads, while in the third set also the TER is subdivided into its constituents. All regressions include four country- and two investment focus dummy variables with France and the domestic investment focus being the base levels, respectively. By the inclusion of these variables systematic return differences between countries and investment foci are accounted for.

The following terms specify the three regression models:

\section{Model (5):}

$$
\begin{aligned}
\alpha_{\mathrm{i}}=\mathrm{c} & +\beta_{1} \text { bank }_{\mathrm{i}}+\beta_{2} \text { active }_{\mathrm{i}}+\beta_{3} \text { retail }_{\mathrm{i}}+\beta_{4} \mathrm{LN} \text { age }_{\mathrm{i}}+\beta_{5} \mathrm{LN} \text { assets }_{\mathrm{i}}+\beta_{6} \text { TSC }_{\mathrm{i}} \\
& +\beta_{7} \text { Germany }_{\mathrm{i}}+\beta_{8} \text { Italy }_{\mathrm{i}}+\beta_{9} \text { Spain }_{\mathrm{i}}+\beta_{10} \mathrm{UK}_{\mathrm{i}}+\beta_{11} \text { European }_{\mathrm{i}}+\beta_{12} \text { global }_{\mathrm{i}}
\end{aligned}
$$

\section{Model (6):}

$$
\begin{aligned}
\alpha_{\mathrm{i}}=\mathrm{c} & +\beta_{1} \text { bank }_{\mathrm{i}}+\beta_{2} \text { active }_{\mathrm{i}}+\beta_{3} \text { retail }_{\mathrm{i}}+\beta_{4} \mathrm{LN}_{\text {age }}+\beta_{5} \mathrm{LN} \text { assets }_{\mathrm{i}}+\beta_{6} \text { TER }_{\mathrm{i}} \\
& +\beta_{7} \text { initial }_{\mathrm{i}}+\beta_{8} \text { redemption }_{\mathrm{i}}+\beta_{9} \text { Germany }_{\mathrm{i}}+\beta_{10} \text { Italy }_{\mathrm{i}}+\beta_{11} \text { Spain }_{\mathrm{i}} \\
& +\beta_{12} \text { UK }_{\mathrm{i}}+\beta_{13} \text { European }_{\mathrm{i}}+\beta_{14} \text { global }_{\mathrm{i}}
\end{aligned}
$$




\section{Model (7):}

$$
\begin{aligned}
& \alpha_{\mathrm{i}}=\mathrm{c}+\beta_{1} \text { bank }_{\mathrm{i}}+\beta_{2} \text { active }_{\mathrm{i}}+\beta_{3} \text { retail }_{\mathrm{i}}+\beta_{4} \mathrm{LN} \text { age }_{\mathrm{i}}+\beta_{5} \mathrm{LN} \text { assets }_{\mathrm{i}} \\
& +\beta_{6} \text { admin }_{\mathrm{i}}+\beta_{7} \text { management }_{\mathrm{i}}+\beta_{8} \text { audit }_{\mathrm{i}}+\beta_{9} \text { subsidy }_{\mathrm{i}}+\beta_{10} \text { custody }_{\mathrm{i}} \\
& +\beta_{11} \text { distribution }_{i}+\beta_{12} \text { performance }_{i}+\beta_{13} \text { other }_{i}+\beta_{14} \text { initial }_{i}+\beta_{15} \text { redemption }_{i} \\
& +\beta_{16} \text { Italy }_{\mathrm{i}}+\beta_{17} \text { Germany }_{\mathrm{i}}+\beta_{18} \text { Spain }_{\mathrm{i}}+\beta_{19} \mathrm{UK}_{\mathrm{i}}+\beta_{20} \text { European }_{\mathrm{i}}+\beta_{21} \text { global }_{\mathrm{i}}
\end{aligned}
$$

where

$$
\begin{aligned}
& \alpha_{i} \quad=4 \text {-factor alpha for fund } \mathrm{i} \\
& \text { bank }_{\mathrm{i}}=\text { Dummy variable which equals } 1 \text { if fund } \mathrm{i} \text { is promoted by a bank } \\
& \text { active }_{\mathrm{i}} \quad=\text { Dummy variable which equals } 1 \text { if fund } \mathrm{i} \text { is actively managed } \\
& \text { retail }_{\mathrm{i}}=\text { Dummy variable which equals } 1 \text { if fund } \mathrm{i} \text { is sold in the retail market } \\
& \text { LN age }_{\mathrm{i}} \quad=\mathrm{LN} \text { of fund i's age in } 2004
\end{aligned}
$$

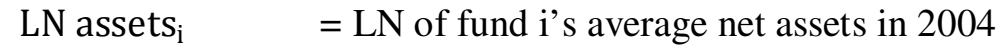

$$
\begin{aligned}
& \mathrm{TER}_{\mathrm{i}} \quad=\text { Total Expense Ratio for fund } \mathrm{i} \text { in } 2004 \\
& \mathrm{TSC}_{\mathrm{i}} \quad=\text { Total Shareholder Cost Ratio for fund } \mathrm{i} \text { in } 2004 \\
& \operatorname{admin}_{\mathrm{i}} \quad=\text { Administrative fee for fund } \mathrm{i} \text { in } 2004
\end{aligned}
$$

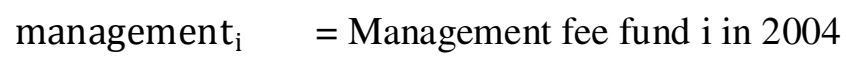

$$
\begin{aligned}
& \text { audit }_{\mathrm{i}} \quad=\text { Audit fee for fund } \mathrm{i} \text { in } 2004 \\
& \text { subsidy }_{\mathrm{i}} \quad=\text { Subsidy fee for fund } \mathrm{i} \text { in } 2004 \\
& \text { custody }_{\mathrm{i}} \quad=\text { Custody fee for fund } \mathrm{i} \text { in } 2004
\end{aligned}
$$

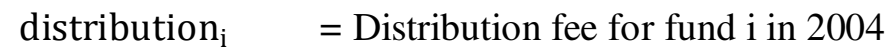

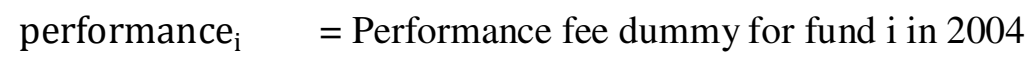

$$
\begin{aligned}
& \text { other }_{\mathrm{i}} \quad=\text { Other fees for fund } \mathrm{i} \text { in } 2004 \\
& \text { initial }_{\mathrm{i}} \quad=\text { Initial load for fund } \mathrm{i} \text { in } 2004
\end{aligned}
$$

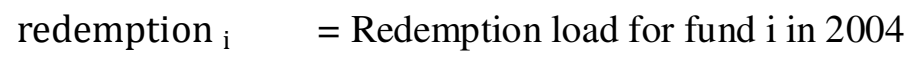

$$
\begin{aligned}
& \text { country }_{\mathrm{i}} \quad=\text { Country dummy variables } \\
& \text { European }_{\mathrm{i}} \quad=\text { Dummy variable which equals } 1 \text { if fund } \mathrm{i} \text { has a European focus } \\
& \text { global }_{\mathrm{i}} \quad=\text { Dummy variable which equals } 1 \text { if fund } \mathrm{i} \text { has a global focus }
\end{aligned}
$$


The results shown in Table 9 confirm the performance of active funds over passive ones. For all three models the active dummy variable's coefficient is highly significant. Its positive values imply that on average active funds significantly outperform passive funds. Furthermore, the bank dummy is also significant and negative, thus indicating a lower riskadjusted performance of bank promoted funds. Giving further evidence to the size effect in the European markets, the coefficient of LN assets $s_{i}$ is for all models positive and significant. While these results are in line with the previous findings, they exhibit a way higher level of significance.

Regarding the expense characteristics no clear overall relationship between the level of expenses and a fund's alpha emerges. The TSC and TER coefficients have negative values, however they are not significant. This is in contrast to Carhart (1997) or Otten and Bams (2002), who both show a significant negative impact of the expense ratio. The subdivision of the TER into the different expense categories leads to two significant coefficients. First of all, the coefficient of the administrative expenses variable is significantly positive, however only at a $10 \%$ level of confidence and secondly, the one of the other expenses variable exhibits the opposite characteristics.

\section{Insert Table 9 about here}

\subsection{Persistence}

Our results so far clearly indicate that the average European mutual fund is not able to add value. We now question this result by examining whether a small subset of funds is able to outperform. More formally we test whether past fund returns are a predictor for future fund returns. Such a performance characteristic is denoted persistence or hot hands effect and has already been investigated in various studies, especially with respect to the US fund market. As discussed before, several authors like Hendricks, Patel, and Zeckhauser (1993) find evidence for short-term performance persistence, while Grinblatt and Titman (1992) or Elton, Gruber, and Blake (1996) document similar effects over longer horizons as well. Nevertheless, in a revolutionary study Carhart (1997) attributes most of this hot hands effect to the one-year stock return momentum of Jegadeesh and Titman (1993) and to differences in the funds' expenses.

Research focused on the European market is rather scarce. Almost the only comprehensive European study investigating performance persistence is conducted by Otten and Bams 
(2002), who investigate the performance of domestically focused mutual funds in five national European markets during the period from 1991 to 1998.

Except for the UK market the authors find only weak evidence for this performance characteristic in Europe, which is contrary to the majority of findings in the US market. However, during the 1990s the European mutual fund markets grew dramatically both in terms of size and sophistication. It might therefore well be that by now their characteristics with respect to performance persistence have changed. In contrast to Otten and Bams, this study employs a longer time series dataset which also covers the period and most of the markets examined by these researchers in 2002 .

To investigate performance persistence in the time series dataset, the funds are assigned to 15 independent categories depending on the national market they are listed in and their investment focus. Replicating the methodology of Hendricks, Patel, and Zeckhauser (1993), at the beginning of each time period the funds in all categories are ranked according to the previous time period's net excess returns. On the basis of this ranking ten equally-weighted decile portfolios are formed, where portfolio 1 contains the funds with the highest past returns and portfolio 10 the funds with the lowest past returns. Portfolios 1 and 10 are by the same measure further subdivided into three sub-portfolios $\mathrm{A}, \mathrm{B}$, and $\mathrm{C}$ to investigate the performance of the extreme performers in more detail. The portfolios are then held over the upcoming period and reformed at the beginning of the next one, which yields a time series of returns for each portfolio based on non-overlapping time periods. Besides these (sub-)decile portfolios also two spread portfolios per fund category are formed. The first one represents the return differences between portfolios 1 and 10, while the second represents those between portfolios $1 \mathrm{~A}$ and 10C.

The return series are regressed on the already discussed Fama French 3-factor and the unconditional and conditional Carhart 4-factor models in order to obtain the risk-adjusted abnormal returns of the different portfolios. Since some studies find hot hands effects only in the short-term while others report them to be existent in the long-term, both the short-term as well as the long-term performance are investigated in the upcoming sections. For this purpose, the persistence analysis is conducted with three different horizons, particularly 6, 12 and 36 months.

Table 10 provides strong evidence in favor of persistence in performance for all countries. Both on excess returns and alpha the performance of past winners persistently is above the 
above of past losers. The strategy of buying past 6 month winners and selling past month losers yields up to $20 \%$ per year. Lengthening the holding period to 12 month decreases the spread but still provides a significant spread for most countries. In line with previous evidence, persistence dies out after about 36 months. That is, the spread of past 36 month winners over 36 months losers is less significant. Again, these results are in sharp contrast to Otten \& Bams (2002) who report only weak evidence for European funds up to 1998.

\section{Insert Table 10 about here}

\section{Conclusion}

This paper revisits the performance of European mutual funds using a more recent and extensive survivorship bias free database of 16,055 equity funds over the 1992-2006 period. Earlier evidence by Otten \& Bams (2002) pointed to an exceptional position of European mutual funds. In contrast to for instance the United States, the authors documented that European funds were able to add value, based on their positive alphas. Otten \& Bams (2002) contributed that to the relative small size of the European mutual fund industry compared to the total stock market (around 13\% in 1998). By 2005 this size has almost doubled to $25 \%$. The main motivation for our study is to examine whether this had an impact on the ability of European mutual funds to beat the market. Our main results are four-fold. First, we indeed find that European mutual funds deliver significantly negative 4-factor Carhart alpha's during this more recent period. The larger current size of the European mutual fund industry makes it more difficult for managers to add value. These results are now more in line with earlier results for US funds. Second, passive funds perform even worse than active funds, leaving us with a puzzle. It might be that passive funds are not pure indextrackers but active funds in disguise. Third, adding back TER's and loads make most alphas insignificantly different from zero. Which means that European fund managers are able to follow the market but charge investors too much for this. Fourth, we find strong persistence in performance. In contrast to Otten \& Bams (2002), in all investigated countries the strategy of buying past winners and selling past losers leads to a both economically and statistically outperformance during 6 and 12 month holding periods. Based on the results in this paper it would be interesting to study the impact of a growing fund sector in emerging markets on fund performance. We leave this for further research. 


\section{REFERENCES}

Banz, R.W. (1981). The Relationship between Return and Market Value of Common Stocks. Journal of Financial Economics, 9, 3-18

Basu, S. (1983). The Relationship between Earnings Yield, Market Value, and Return for NYSE Common Stocks: Further Evidence. Journal of Financial Economics, 12, 129-156

Berk, J.B. and Green, R.C. (2004). Mutual Fund Flows and Performance in Rational Markets. Journal of Political Economy, 112 (6), 1269-1294

Bollen, N.P.B. and Busse, J.A. (2004). Short-term Persistence in Mutual Fund Performance. The Review of Financial Studies, 18 (2), 569-597

Brown, S.J. and Goetzman, W.N. (1995). Performance Persistence. The Journal of Finance, 50 (2), 679-698

Carhart, M. (1997). On Persistence in Mutual Fund Performance. Journal of Finance, 52, 57 82

Chan, L. and Lakonishok, J. (1993). Are the Reports of Beta's Death Premature? The Journal of Portfolio Management, 19 (4), 51-62

Chan, Z. and Knez, P.J. (1996). Portfolio performance Measurement: Theory and Applications. Review of Financial Studies, 9, 511-556

Chang, E. and Lewellen, E. (1984). Market Timing and Mutual Fund Investment Performance. The Journal of Business, 57 (1), 57-72

Chen, J., Hong, H., Huang, M. and Kubick, J. D. (2004). Does Firm Size Erode Mutual Fund Performance? The Role of Liquidity and Organization. American Economic Review, 44, 1276-1302

Chen, Z. and Knez, P.J. (1996). Momentum Strategies. Journal of Finance, 52, 57-82 
Daniel, K., Grinblatt, M., Titman, S., and Wermers, R. (1997). Measuring Mutual Fund Performance with Characteristic-Based Benchmarks. Journal of Finance, 52, 1035-1058

EFAMA (2006). Trends in European Investment Funds. 4th Edition.

Elton, E.J., Gruber, M.J., and Blake, C. (1996). The Persistence of Risk-Adjusted Mutual Performance. Journal of Business, 69, 133-157

Elton, E.J., Gruber, M.J., Busse, J. (2004). Are Investors Rational? Choices among Index Funds. Journal of Finance, 59, 261-288

Elton, E.J., Gruber, M.J., Das, S. and Hlavka, M. (1993). Efficiency with Costly Information: A Reinterpretation of Evidence from Managed Portfolios. Review of Financial Studies, 6, 122.

Fama, E. and French, K. (1992). The Cross-Section of Expected Stock Returns. Journal of Finance, 47 (2), 427-465

Fama, E. \& French, K. (1993). Common risk factors in the returns on stocks and bonds. Journal of Financial Economics, 33, 3-56.

Fama, E. \& French, K. (1998). Value versus growth: The International Evidence. Journal of Finance, 53

Ferreira, M.A., Miguel, A.F. and Ramos, S. (2006). The Determinants of Mutual Fund Performance: A Cross-Country Study. Swiss Finance Institute Research Paper Series, 30 (6)

Ferson, W. and Schadt, R. (1996). Measuring Fund Strategy and Performance in Changing Economic Conditions. Journal of Finance, 51, 425-462

Goetzmann, W. N. and Ibbotson, R. G. (1994). Do Winners Repeat? Journal of Portfolio Management, 20, 9. 
Grinblatt, M. and Titman, S. (1989). Mutual Fund Performance: An Analysis of Quarterly Portfolio Holdings. The Journal of Business, 62, 393.

Grinblatt, M. and Titman, S. (1992). The Persistence of Mutual Fund Performance. Journal of Finance, 47, 1977-1984

Grinblatt, M., Titman, S. and Wermers, R. (1995). Momentum investment strategies, portfolio performance, and herding: A study of mutual fund behavior. The American Economic Review. 85 (5), 1088-1105

Gruber, M. (1996). Another Puzzle: The Growth in Actively Managed Mutual Fund. Journal of Finance, 51, 783-810

Hendricks, D., Patel, J. and Zeckhauser, R. (1993). Hot Hands in Mutual Funds: Short-Run Persistence of Relative Performance. Journal of Finance, 48, 93-130

Henricksson, R. (1984). Market Timing and Mutual Fund Performance: An Empirical Investigation. The Journal of Business, 57 (1), 73-96

Henricksson, R.D. and Merton, R.C. (1981). On Market Timing and Investment Performance. Statistical Procedures for Evaluating Forecasting Skills. Journal of Business, 54 (4), 513-533

Huij, J. and Derwall, J. (2007). "Hot Hands" in Bond Funds. Journal of Banking \& Finance

Ibbotson, R.G. and Patel, A.K. (2002). Do Winners Repeat With Style? Yale School of Management Working Paper

ICI (2008). Investment Company Factcook. $48^{\text {th }}$ Edition.

Ippolito, R. A. (1989). Efficiency with Costly Information: A Study of Mutual Fund Performance. Quarterly Journal of Economics, 104, 1-23

Jegadeesh, N. and Titman, S. (1993). Returns to buying winners and selling losers: Implications for stock market efficiency. Journal of Finance, 48, 65-91 
Jensen, M.C. (1968). The Performance of Mutual Funds in the Period 1945-1964. Journal of Finance, 23, 289-416

Jensen, M.C. (1969). Risk, the Pricing of Capital Assets and Evaluation of Investment Portfolios. Journal of Business, 43, 167-247

Korkeamaki, T. and Smythe, T. (2004). Effects of Market Segmentation and Bank Concentration on Mutual Fund Expenses and Returns: Evidence from Finland. European Financial Management, 10, 413-438

Kothari, S., Shanken, J. and Sloan, R. (1995). Another Look at the Cross-Section of Expected Stock Returns. Journal of Finance 50 (1), 185-224

Malkiel, B.G. (1995). Returns from Investing in Equity Mutual Funds 1971 to 1991. Journal of Finance, 50, 549-572

Malkiel, B.G. (2003). Passive Investment Strategies and Efficient Markets. European Financial Management, 9, 1-10

Otten, R. and Bams, D. (2002). European Mutual Fund Performance. European Financial Management, 8, 75-101

Rouwenhorst, K.G. (1998). Internation Momentum Strategies. The Journal of Finance, 53 (1), 267-284

Teo, M. and Woo, S.J. (2001). Persistence in Style-Adjusted Mutual Fund Returns. Harvard University Working Paper

Wermers, R. (2000). Mutual Fund Performance: An Empirical Decomposition into StockPicking Talent, Style, Transaction Costs, and Expenses. The Journal of Finance, 55 (4), $1655-1$ 
Figure 1: Global Mutual Fund Market - Asset Allocation Across Regions

This figure illustrates the allocation of the worldwide mutual fund assets across the four major global regions at the end of 2005, based on the funds' domiciles. Due to the immense size of the US market, the American region is split up into the USA and other American countries.

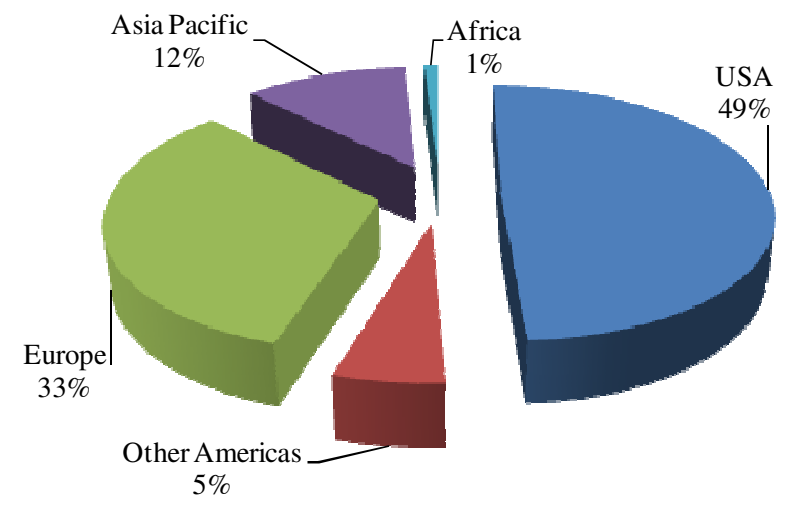

Source: EFAMA, 2006 
Figure 2: European Mutual Fund Market - Asset Allocation Across Countries

This figure illustrates the allocation of European mutual fund assets across the European countries at the end of 2005 , based on the funds' domiciles.

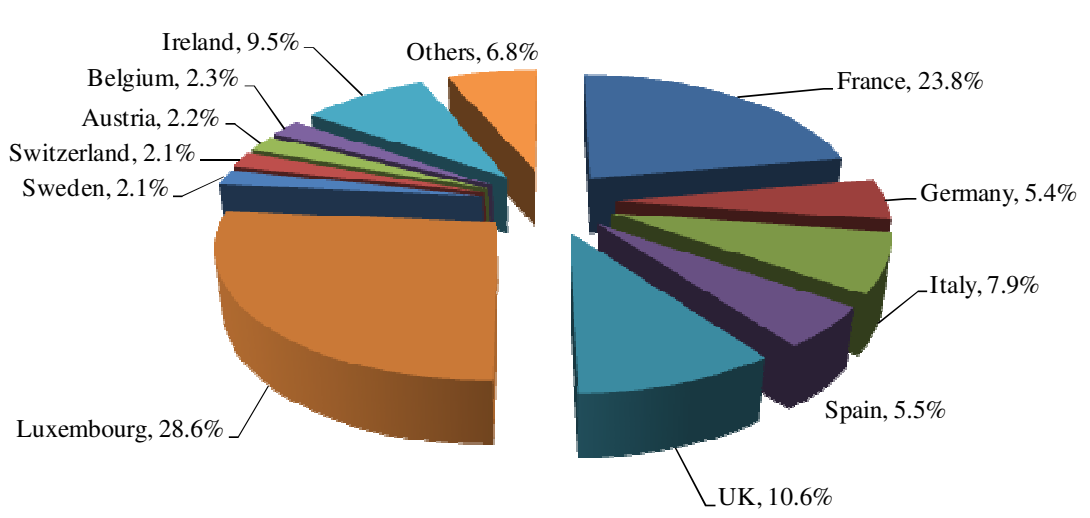

Source: EFAMA, 2006 
Figure 3: Historical Development of TER, TSC and Load Charges

The graphs display the historical average TSC, TER and load charges of the mutual funds covered by the crosssectional dataset. Averages are calculated per country. For Germany no information on the load charges is available.
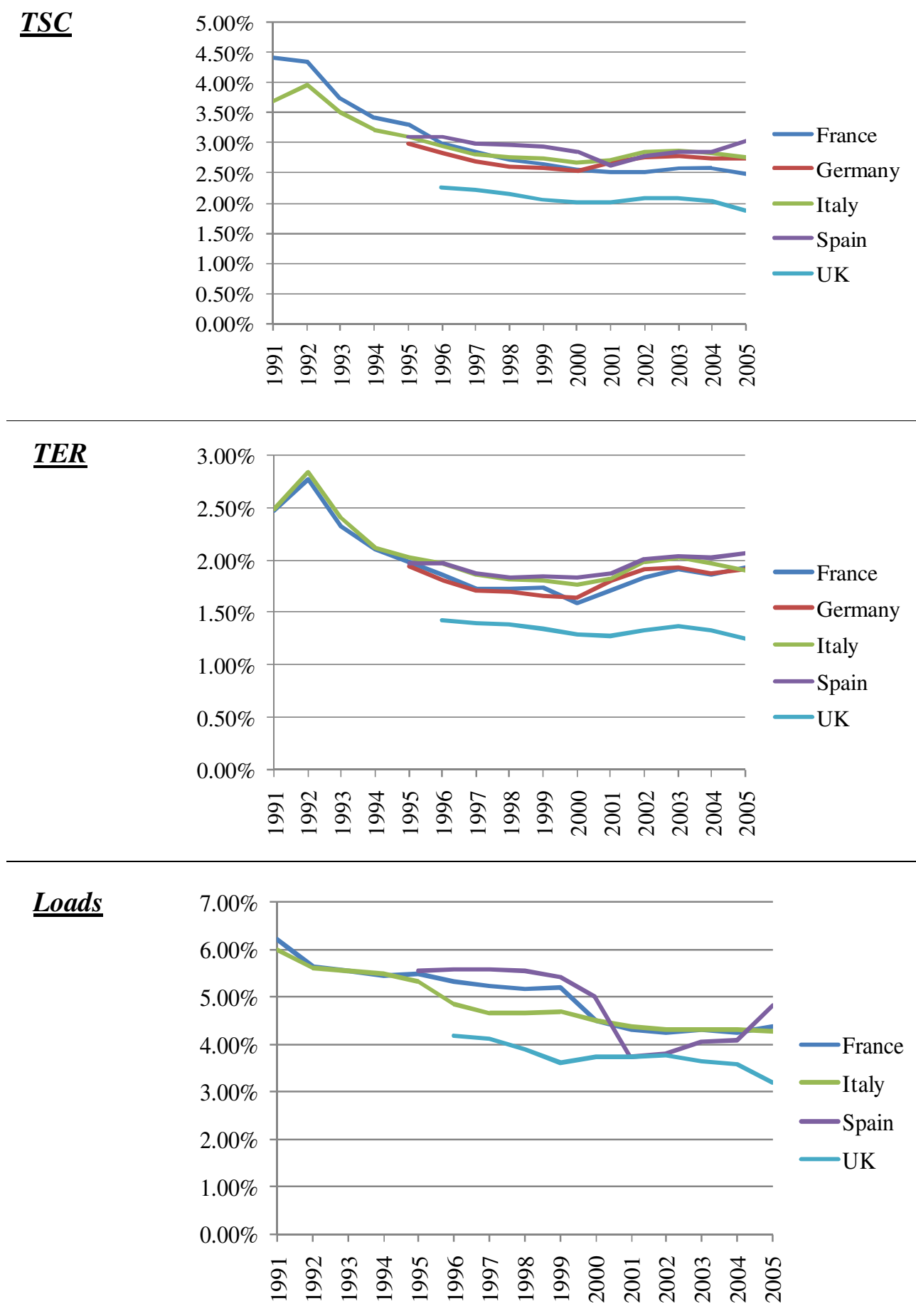
Table 1: Mutual Fund Total Net Assets by Region and Fund Segment

The table reports the total net assets of the different fund segments in the four major global regions and in the most important fund domicile countries. All figures are in EUR Million and based on the funds' domiciles.

\begin{tabular}{lcccccccc}
\hline & & & & & & & & \multicolumn{3}{c}{ Money } \\
& Total Assets & Equity & Bond & Balanced & Market & Other Funds & Funds & Average Size \\
\hline World & $15,765,552$ & $7,062,399$ & $2,932,773$ & $1,329,176$ & $2,851,980$ & $1,126,269$ & 60,158 & 262 \\
Americas & $8,686,956$ & $4,400,409$ & $1,418,127$ & 619,360 & $1,778,651$ & 470,409 & 16,239 & 535 \\
USA & $7,808,078$ & $4,187,523$ & $1,150,557$ & 480,888 & $1,729,708$ & 259,402 & 8,452 & 924 \\
Asia Pacific & $1,832,728$ & 820,335 & 311,202 & 63,318 & 215,741 & 422,132 & 11,894 & 154 \\
Africa & 63,172 & 18,056 & 3,483 & 10,001 & 15,481 & 16,151 & 844 & 75 \\
Europe & $5,182,696$ & $1,823,599$ & $1,199,961$ & 636,497 & 842,107 & 217,577 & 31,133 & 166 \\
France & $1,155,100$ & 333,700 & 181,000 & 250,900 & 389,500 & - & 7,758 & 149 \\
Germany & 262,365 & 120,380 & 78,550 & 18,935 & 31,863 & 12,637 & 1,270 & 207 \\
Italy & 381,889 & 78,562 & 146,066 & 85,702 & 71,559 & - & 1,035 & 369 \\
Spain & 268,598 & 93,452 & 73,762 & 46,933 & 54,451 & - & 2,672 & 101 \\
UK & 512,734 & 357,361 & 75,733 & 37,210 & 3,940 & 38,490 & 2,156 & 238 \\
Luxembourg & $1,386,611$ & 538,768 & 437,397 & 96,441 & 201,098 & 112,907 & 7,222 & 192 \\
Ireland ${ }^{1}$ & 462,955 & - & - & - & - & - & 2,127 & 218 \\
& & & & & & & & \\
\hline
\end{tabular}

${ }^{1}$ For Ireland no individual data on the fund segments is available.

Source: EFAMA, 2006 
Table 2: Equity Mutual Funds as a Percentage of Total Stock Market Capitalization

The table reports the sizes of the equity mutual fund markets in percentage of the total stock market capitalization in the respective countries or region between 1995 and 2005 . The equity mutual fund market figures are based on the asset values of funds domiciled in the respective countries. Since the most part of funds domiciled in Luxembourg and Ireland is sold in other national markets their assets are allocated to the other European countries, based on the yearly proportions of the remaining European equity mutual fund market which is made up by the equity funds domiciled in their respective legislations. The value of equity mutual funds domiciled in Ireland are calculated by multiplying the total mutual funds asset values by the overall proportion of the European mutual fund market which is made up by equity mutual funds in the respective year.

\begin{tabular}{lccccccccccc}
\hline & $\mathbf{1 9 9 5}$ & $\mathbf{1 9 9 6}$ & $\mathbf{1 9 9 7}$ & $\mathbf{1 9 9 8}$ & $\mathbf{1 9 9 9}$ & $\mathbf{2 0 0 0}$ & $\mathbf{2 0 0 1}$ & $\mathbf{2 0 0 2}$ & $\mathbf{2 0 0 3}$ & $\mathbf{2 0 0 4}$ & $\mathbf{2 0 0 5}$ \\
\hline Europe $^{\mathbf{1}}$ & $11 \%$ & $11 \%$ & $12 \%$ & $13 \%$ & $15 \%$ & $17 \%$ & $18 \%$ & $20 \%$ & $21 \%$ & $22 \%$ & $25 \%$ \\
$\quad$ France & $15 \%$ & $16 \%$ & $17 \%$ & $18 \%$ & $16 \%$ & $19 \%$ & $22 \%$ & $27 \%$ & $29 \%$ & $34 \%$ & $37 \%$ \\
Germany & $7 \%$ & $6 \%$ & $8 \%$ & $9 \%$ & $12 \%$ & $16 \%$ & $15 \%$ & $17 \%$ & $17 \%$ & $17 \%$ & $19 \%$ \\
Italy & $12 \%$ & $10 \%$ & $14 \%$ & $17 \%$ & $25 \%$ & $26 \%$ & $27 \%$ & $23 \%$ & $23 \%$ & $20 \%$ & $19 \%$ \\
Spain & $1 \%$ & $2 \%$ & $8 \%$ & $14 \%$ & $17 \%$ & $15 \%$ & $13 \%$ & $12 \%$ & $15 \%$ & $17 \%$ & $19 \%$ \\
UK & $12 \%$ & $12 \%$ & $11 \%$ & $12 \%$ & $14 \%$ & $15 \%$ & $17 \%$ & $17 \%$ & $18 \%$ & $20 \%$ & $23 \%$ \\
USA & $20 \%$ & $22 \%$ & $21 \%$ & $23 \%$ & $21 \%$ & $21 \%$ & $18 \%$ & $21 \%$ & $28 \%$ & $31 \%$ & $29 \%$ \\
\hline
\end{tabular}

${ }^{1}$ Covers only the five European countries this study is focused on.

Sources: EFAMA, 2006 and Eurostat, 2008 
Table 3: Summary Statistics - Fund Returns

The table reports summary statistics of the time series dataset and the employed market benchmarks. Returns and standard deviations are annualized. All returns are net of expenses and calculated as equally weighted averages. The "Live Funds" categories include only funds being active during March 2006. Furthermore for each country, three investment focus categories are set up, including funds with a domestic, European and global investment focus, respectively. All returns and standard deviation figures are in percentage terms.

\begin{tabular}{|c|c|c|c|}
\hline \multicolumn{4}{|l|}{ Fund Returns } \\
\hline & Number of Funds & Return & Standard Deviation \\
\hline \multicolumn{4}{|l|}{ France } \\
\hline Live Funds & 2815 & 9.4 & 14.3 \\
\hline All Funds & 3813 & 9.5 & 14.4 \\
\hline Domestic & 543 & 11.8 & 16.9 \\
\hline European & 1395 & 10.6 & 15.0 \\
\hline Global & 1875 & 8.3 & 14.7 \\
\hline \multicolumn{4}{|l|}{ Germany } \\
\hline Live Funds & 2796 & 9.7 & 14.9 \\
\hline All Funds & 3658 & 9.4 & 15.1 \\
\hline Domestic & 160 & 10.1 & 19.8 \\
\hline European & 1186 & 11.4 & 15.5 \\
\hline Global & 2312 & 8.2 & 15.4 \\
\hline \multicolumn{4}{|l|}{ Italy } \\
\hline Live Funds & 1830 & 9.5 & 14.1 \\
\hline All Funds & 2424 & 9.2 & 14.2 \\
\hline Domestic & 142 & 13.2 & 19.2 \\
\hline European & 724 & 11.3 & 15.2 \\
\hline Global & 1558 & 7.6 & 14.4 \\
\hline \multicolumn{4}{|l|}{ Spain } \\
\hline Live Funds & 1845 & 9.5 & 14.5 \\
\hline All Funds & 2262 & 10.2 & 14.7 \\
\hline Domestic & 145 & 11.4 & 17.1 \\
\hline European & 717 & 11.3 & 15.3 \\
\hline Global & 1400 & 9.6 & 15.4 \\
\hline \multicolumn{4}{|l|}{ UK } \\
\hline Live Funds & 2824 & 11.4 & 14.2 \\
\hline All Funds & 3898 & 11.0 & 14.2 \\
\hline Domestic & 944 & 11.8 & 13.5 \\
\hline European & 689 & 13.2 & 15.7 \\
\hline Global & 2265 & 10.1 & 15.2 \\
\hline
\end{tabular}

\begin{tabular}{lcc}
\hline Market Benchmark Returns & & \\
\hline Domestic & Return & Standard Deviation \\
France & 12.0 & 17.5 \\
Germany & 11.3 & 17.7 \\
Italy & 10.1 & 24.3 \\
Spain & 11.7 & 20.3 \\
UK & 13.1 & 15.5 \\
& & \\
Europe & 11.6 & 15.5 \\
& & \\
Global & 9.3 & 15.4
\end{tabular}


Table 4: Summary Statistics - Benchmarks

The table reports summary statistics for the employed benchmarks. Excess market returns are calculated by subtracting the one-month interbank rate in the respective country from the total returns. Returns and standard deviations are annualized. All returns and standard deviation figures are in percentage terms.

\begin{tabular}{|c|c|c|c|c|c|c|}
\hline & \multirow[b]{2}{*}{ Return } & \multirow[b]{2}{*}{ Standard Deviation } & \multicolumn{4}{|c|}{ Cross-Correlations } \\
\hline & & & $\mathbf{M}$ & SMB & HML & MOM \\
\hline \multicolumn{7}{|c|}{ Domestic Investment Focus } \\
\hline \multicolumn{7}{|l|}{ France } \\
\hline Excess Market Return & 7.4 & 17.5 & 1.0 & & & \\
\hline SMB & 0.3 & 10.1 & -0.4 & 1.0 & & \\
\hline HML & 1.3 & 17.1 & 0.0 & 0.0 & 1.0 & \\
\hline MOM & -0.7 & 18.4 & -0.1 & 0.1 & -0.6 & 1.0 \\
\hline \multicolumn{7}{|l|}{ Germany } \\
\hline Excess Market Return & 7.2 & 17.7 & 1.0 & & & \\
\hline SMB & -2.7 & 11.8 & -0.7 & 1.0 & & \\
\hline HML & 6.8 & 15.9 & -0.1 & -0.1 & 1.0 & \\
\hline MOM & -4.0 & 21.2 & -0.1 & 0.1 & -0.7 & 1.0 \\
\hline \multicolumn{7}{|l|}{ Italy } \\
\hline Excess Market Return & 4.1 & 24.4 & 1.0 & & & \\
\hline SMB & -2.8 & 11.6 & -0.3 & 1.0 & & \\
\hline HML & 4.3 & 18.2 & -0.1 & 0.4 & 1.0 & \\
\hline MOM & 2.8 & 19.2 & 0.1 & -0.2 & -0.4 & 1.0 \\
\hline \multicolumn{7}{|l|}{ Spain } \\
\hline Excess Market Return & 6.0 & 20.4 & 1.0 & & & \\
\hline SMB & 0.6 & 12.5 & -0.5 & 1.0 & & \\
\hline HML & 7.7 & 17.4 & -0.3 & 0.4 & 1.0 & \\
\hline MOM & -1.2 & 18.4 & 0.0 & -0.2 & -0.4 & 1.0 \\
\hline \multicolumn{7}{|l|}{ UK } \\
\hline Excess Market Return & 7.1 & 14.0 & 1.0 & & & \\
\hline SMB & 3.3 & 12.2 & 0.1 & 1.0 & & \\
\hline HML & 4.1 & 12.7 & 0.1 & 0.2 & 1.0 & \\
\hline MOM & 6.2 & 17.6 & -0.1 & 0.2 & -0.4 & 1.0 \\
\hline \multicolumn{7}{|c|}{ European Investment Focus } \\
\hline \multicolumn{7}{|l|}{ France } \\
\hline Excess Market Return & 7.1 & 15.6 & 1.0 & & & \\
\hline SMB & 1.2 & 7.0 & -0.2 & 1.0 & & \\
\hline HML & 5.7 & 10.7 & 0.0 & 0.1 & 1.0 & \\
\hline MOM & 1.7 & 15.6 & -0.1 & 0.2 & -0.6 & 1.0 \\
\hline \multicolumn{7}{|l|}{ Germany } \\
\hline Excess Market Return & 7.5 & 15.6 & 1.0 & & & \\
\hline SMB & 1.2 & 7.0 & -0.2 & 1.0 & & \\
\hline HML & 5.7 & 10.7 & 0.0 & 0.1 & 1.0 & \\
\hline MOM & 1.7 & 15.6 & -0.1 & 0.2 & -0.6 & 1.0 \\
\hline
\end{tabular}


Table 4 (continued): Summary Statistics - Benchmarks

\begin{tabular}{|c|c|c|c|c|c|c|}
\hline & \multirow[b]{2}{*}{ Return } & \multirow[b]{2}{*}{ Standard Deviation } & \multicolumn{4}{|c|}{ Cross-Correlations } \\
\hline & & & $\mathbf{M}$ & SMB & HML & MOM \\
\hline \multicolumn{7}{|l|}{ Italy } \\
\hline Excess Market Return & 5.6 & 15.6 & 1.0 & & & \\
\hline SMB & 1.2 & 7.0 & -0.2 & 1.0 & & \\
\hline HML & 5.7 & 10.7 & 0.0 & 0.1 & 1.0 & \\
\hline MOM & 1.7 & 15.6 & -0.1 & 0.2 & -0.6 & 1.0 \\
\hline \multicolumn{7}{|l|}{ Spain } \\
\hline Excess Market Return & 5.9 & 15.5 & 1.0 & & & \\
\hline SMB & 1.2 & 7.0 & -0.2 & 1.0 & & \\
\hline HML & 5.7 & 10.7 & 0.0 & 0.1 & 1.0 & \\
\hline MOM & 1.7 & 15.6 & -0.1 & 0.2 & -0.6 & 1.0 \\
\hline \multicolumn{7}{|l|}{ UK } \\
\hline Excess Market Return & 5.6 & 14.7 & 1.0 & & & \\
\hline SMB & 1.2 & 7.0 & -0.3 & 1.0 & & \\
\hline HML & 5.7 & 10.7 & 0.0 & 0.1 & 1.0 & \\
\hline MOM & 1.7 & 15.6 & -0.1 & 0.2 & -0.6 & 1.0 \\
\hline \multicolumn{7}{|l|}{ Global Investment Focus } \\
\hline \multicolumn{7}{|l|}{ France } \\
\hline Excess Market Return & 4.8 & 15.4 & 1.0 & & & \\
\hline SMB & -0.4 & 8.3 & 0.1 & 1.0 & & \\
\hline HML & 6.2 & 14.5 & -0.1 & 0.5 & 1.0 & \\
\hline MOM & 3.3 & 16.5 & 0.0 & 0.0 & -0.5 & 1.0 \\
\hline \multicolumn{7}{|l|}{ Germany } \\
\hline Excess Market Return & 5.2 & 15.4 & 1.0 & & & \\
\hline SMB & -0.4 & 8.3 & 0.1 & 1.0 & & \\
\hline HML & 6.2 & 14.5 & -0.1 & 0.5 & 1.0 & \\
\hline MOM & 3.3 & 16.5 & 0.0 & 0.0 & -0.5 & 1.0 \\
\hline \multicolumn{7}{|l|}{ Italy } \\
\hline Excess Market Return & 3.2 & 15.4 & 1.0 & & & \\
\hline SMB & -0.4 & 8.3 & 0.1 & 1.0 & & \\
\hline HML & 6.2 & 14.5 & -0.1 & 0.5 & 1.0 & \\
\hline MOM & 3.3 & 16.5 & 0.0 & 0.0 & -0.5 & 1.0 \\
\hline \multicolumn{7}{|l|}{ Spain } \\
\hline Excess Market Return & 3.6 & 15.4 & 1.0 & & & \\
\hline SMB & -0.4 & 8.3 & 0.1 & 1.0 & & \\
\hline HML & 6.2 & 14.5 & -0.1 & 0.5 & 1.0 & \\
\hline MOM & 3.3 & 16.5 & 0.0 & 0.0 & -0.5 & 1.0 \\
\hline \multicolumn{7}{|l|}{ UK } \\
\hline Excess Market Return & 3.3 & 16.1 & 1.0 & & & \\
\hline SMB & -0.4 & 8.3 & 0.3 & 1.0 & & \\
\hline HML & 6.2 & 14.5 & 0.0 & 0.5 & 1.0 & \\
\hline MOM & 3.3 & 16.5 & -0.1 & 0.0 & -0.5 & 1.0 \\
\hline
\end{tabular}


Table 5: Explanatory Power of Models (1), (2), and (3)

All funds of the time series dataset are categorized by country and investment focus. On the basis of these categories equally weighted portfolios are formed. Models (1), (2) and (3) are estimated over the full sample period. The Log $\mathrm{L}$ - Ratios are calculated by multiplying the difference between the Log $\mathrm{L}$ values of the models reported on the right and on the left of the respective ratio by 2 . The corresponding significance levels are obtained from the asymptotic chi-square distribution. All standard errors are autocorrelation and Newey-West heteroskedasticity consistent. Alphas are annualized. The alpha distribution shows the percentages of alphas which are significantly negative $(-)$, significantly positive (+) and insignificantly different from zero (0).

$* / * * / * * *$ denotes significance at the $10 \% / 5 \% / 1 \%$ level.

\begin{tabular}{|c|c|c|c|c|c|c|c|c|c|c|c|c|c|c|c|c|c|c|}
\hline & \multirow{2}{*}{$\begin{array}{l}\text { No. of } \\
\text { Funds }\end{array}$} & \multicolumn{3}{|c|}{ CAPM } & \multirow{2}{*}{$\begin{array}{c}\text { Log L - } \\
\text { Ratio }\end{array}$} & \multicolumn{5}{|c|}{ Fama French } & \multirow{2}{*}{$\begin{array}{c}\log \mathrm{L} \text { - } \\
\text { Ratio }\end{array}$} & \multicolumn{7}{|c|}{ Carhart } \\
\hline & & Alpha & M & $\operatorname{adj.} R^{2}$ & & Alpha & $\mathbf{M}$ & SMB & HML & $\operatorname{adj} . R^{2}$ & & Alpha & M & SMB & HML & MOM & $\operatorname{adj} . R^{2}$ & $\alpha$ Distr. -/0/+ \\
\hline \multicolumn{19}{|l|}{ France } \\
\hline Domestic & 543 & -2.49 & $0.85 * * *$ & 0.77 & $66.73 * * *$ & $-3.51 * *$ & $0.97 * * *$ & $0.50 * * *$ & -0.02 & 0.85 & $4.18 * *$ & $-3.44 * *$ & $0.96 * * *$ & $0.50 * * * *$ & $-0.07 *$ & $-0.07 * *$ & 0.85 & $46 / 52 / 3$ \\
\hline Europe & 1395 & $-2.42 * *$ & $0.95 * * *$ & 0.92 & $34.60 * * *$ & $-2.17 * *$ & $0.97 * * *$ & $0.23 * * *$ & $-0.12 * * *$ & 0.93 & $6.18 * * *$ & -1.79 & $0.97 * * *$ & $0.26 * * *$ & $-0.17 * * *$ & $-0.06 * *$ & 0.93 & $33 / 65 / 2$ \\
\hline Global & 1875 & -3.36 & $0.91 * * *$ & 0.73 & $82.21 * * *$ & -2.95 & $0.92 * * *$ & $-0.50 * * * *$ & $-0.11 * * *$ & 0.83 & 0.31 & $-3.14 *$ & $0.92 * * *$ & $-0.52 * * *$ & $-0.09 *$ & 0.02 & 0.83 & $11 / 87 / 2$ \\
\hline \multicolumn{19}{|l|}{ Germany } \\
\hline Domestic & 159 & $-4.45 * * *$ & $1.11 * * *$ & 0.95 & $10.76 * * *$ & $-4.77^{* * *}$ & $1.18 * * *$ & $0.14 * * *$ & 0.03 & 0.96 & $13.53 * * *$ & $-4.53 * * *$ & $1.16 * * *$ & $0.13 * * *$ & -0.04 & $-0.07 * * *$ & 0.96 & $65 / 34 / 1$ \\
\hline Europe & 1187 & $-2.14 * * *$ & 1.02 *** & 0.96 & $32.19 * * *$ & $-1.91 * *$ & $1.03 * * *$ & $0.14 * * *$ & $-0.09 * * *$ & 0.97 & 0.35 & $-1.85 * *$ & $1.03 * * *$ & 0.14 *** & $-0.10 * * *$ & -0.01 & 0.97 & $31 / 67 / 2$ \\
\hline Global & 2312 & -3.44 & $0.99^{* * *}$ & 0.77 & $93.65 * * *$ & $-2.95 *$ & $1.01 * * *$ & $-0.52 * * * *$ & $-0.13 * * *$ & 0.86 & 0.66 & $-3.23 *$ & $1.01 * * *$ & $-0.55 * * *$ & $-0.10 * *$ & 0.03 & 0.86 & $12 / 86 / 2$ \\
\hline \multicolumn{19}{|l|}{ Italy } \\
\hline Domestic & 142 & 2.22 & $0.72 * * *$ & 0.87 & $25.72 * * *$ & $3.23 *$ & $0.74 * * *$ & $0.20 * * *$ & $-0.12 * * *$ & 0.89 & 0.17 & $3.28 *$ & $0.74 * * *$ & $0.20 * * *$ & $-0.13 * * *$ & -0.01 & 0.89 & 18/70/12 \\
\hline Europe & 724 & $-1.92 * *$ & $0.99 * * *$ & 0.96 & $27.72 * * *$ & $-1.62 * *$ & $1.00 * * *$ & $0.11 * * *$ & $-0.09 * * *$ & 0.97 & 0.03 & $-1.63 * *$ & $1.00 * * *$ & $0.11 * * *$ & $-0.09 * * * *$ & 0.00 & 0.97 & $37 / 61 / 2$ \\
\hline Global & 1558 & -3.22 & $0.94 * * *$ & 0.77 & $85.94 * * *$ & $-2.77 *$ & $0.95 * * *$ & $-0.47 * * *$ & $-0.11 * * *$ & 0.86 & 1.18 & $-3.11 *$ & $0.95 * * *$ & $-0.50 * * *$ & $-0.08 *$ & 0.04 & 0.86 & $17 / 82 / 1$ \\
\hline \multicolumn{19}{|l|}{ Spain } \\
\hline Domestic & 145 & -1.05 & $0.79 * * *$ & 0.88 & 1.19 & -0.81 & $0.78 * * *$ & -0.02 & -0.02 & 0.88 & $3.42 *$ & -0.67 & $0.78 * * *$ & -0.02 & -0.04 & $-0.05 *$ & 0.88 & $34 / 63 / 3$ \\
\hline Europe & 717 & $-2.32 * * *$ & $1.00 * * *$ & 0.97 & 17.10 ** & $-2.02 * * *$ & $1.01 * * *$ & $0.08 * *$ & $-0.08 * * * *$ & 0.97 & 1.16 & $-1.91 * *$ & $1.01 * * *$ & $0.09 * * *$ & $-0.09 * * *$ & -0.02 & 0.97 & $33 / 65 / 2$ \\
\hline Global & 1400 & -3.46 & $0.99 * * *$ & 0.76 & $76.71 * * *$ & -3.00 & $1.00 * * *$ & $-0.49 * * *$ & $-0.12 * * *$ & 0.85 & 0.74 & $-3.31 *$ & $1.01 * * *$ & $-0.52 * * *$ & $-0.09 *$ & 0.03 & 0.84 & $14 / 85 / 1$ \\
\hline \multicolumn{19}{|l|}{ UK } \\
\hline Domestic & 944 & $-2.12 *$ & $0.93 * * *$ & 0.90 & $66.23 * * *$ & $-2.66 * * *$ & $0.90 * * *$ & $0.20 * * *$ & 0.01 & 0.93 & $5.69 *$ & $-2.32 * *$ & $0.90 * * *$ & $0.22 * * *$ & -0.02 & $-0.04 * *$ & 0.93 & $39 / 58 / 3$ \\
\hline Europe & 689 & -0.31 & $1.02 * * *$ & 0.89 & $25.07 * * *$ & 0.02 & $1.05 * * *$ & $0.22 * * *$ & $-0.13 * * *$ & 0.90 & 0.18 & -0.07 & $1.05 * * *$ & $0.22 * * *$ & $-0.12 * * *$ & 0.01 & 0.90 & $18 / 78 / 4$ \\
\hline Global & 2265 & -1.38 & $0.87 * * *$ & 0.75 & $42.23 * * *$ & -1.38 & $0.93 * * *$ & $-0.40 * * *$ & -0.06 & 0.81 & $3.61 *$ & -2.08 & $0.94 * * *$ & $-0.46 * * *$ & 0.00 & $0.08 *$ & 0.81 & $6 / 90 / 4$ \\
\hline
\end{tabular}


Table 6: Unconditional vs. conditional Carhart 4-Factor Model

All funds of the time series dataset are categorized by country and investment focus. On the basis of these categories equally weighted portfolios are formed. The unconditional and conditional Carhart 4-factor models are estimated over the full sample period. All standard errors are autocorrelation and Newey-West heteroskedasticity consistent. Wald Tests are conducted to examine whether the conditional regression variables add significant explanatory power to the unconditional Carhart model. Alphas are annualized. $* / * * / * * *$ denotes significance at the $10 \% / 5 \% / 1 \%$ level.

\begin{tabular}{|c|c|c|c|c|c|}
\hline & \multicolumn{2}{|c|}{ Unconditional Carhart } & \multicolumn{2}{|c|}{ Conditional Carhart } & \multirow[b]{2}{*}{ Wald (p-value) } \\
\hline & Alpha & adj. R2 & Alpha & adj. R2 & \\
\hline \multicolumn{6}{|l|}{$\begin{array}{l}\text { France } \\
\text { ran }\end{array}$} \\
\hline Domestic & $-3.44 \% * *$ & 0.85 & $-3.29 \% *$ & 0.88 & 0.0001 \\
\hline Europe & $-1.79 \%$ & 0.93 & $-2.47 \% * *$ & 0.96 & 0.0000 \\
\hline Global & $-3.14 \% *$ & 0.83 & $-2.31 \%$ & 0.85 & 0.0216 \\
\hline \multicolumn{6}{|l|}{ Germany } \\
\hline Domestic & $-4.53 \% * * *$ & 0.96 & $-4.57 \% * * *$ & 0.96 & 0.0017 \\
\hline Europe & $-1.85 \% * *$ & 0.97 & $-2.52 \% * * *$ & 0.98 & 0.0000 \\
\hline Global & $-3.23 \% *$ & 0.86 & $-2.30 \%$ & 0.86 & 0.5520 \\
\hline \multicolumn{6}{|l|}{ Italy } \\
\hline Domestic & $3.28 \% *$ & 0.89 & $-2.01 \% *$ & 0.96 & 0.0000 \\
\hline Europe & $-1.63 \% * *$ & 0.97 & $-2.92 \% * * *$ & 0.98 & 0.0000 \\
\hline Global & $-3.11 \% *$ & 0.86 & $-2.80 \%$ & 0.87 & 0.1889 \\
\hline \multicolumn{6}{|l|}{ Spain } \\
\hline Domestic & $-0.67 \%$ & 0.88 & $-2.31 \% *$ & 0.93 & 0.0000 \\
\hline Europe & $-1.91 \% * *$ & 0.97 & $-3.04 \% * * *$ & 0.98 & 0.0011 \\
\hline Global & $-3.31 \% *$ & 0.84 & $-2.81 \%$ & 0.85 & 0.2384 \\
\hline \multicolumn{6}{|l|}{ UK } \\
\hline Domestic & $-2.32 \% * *$ & 0.93 & $-1.62 \%$ & 0.93 & 0.1969 \\
\hline Europe & $-0.07 \%$ & 0.90 & $-0.49 \%$ & 0.91 & 0.4036 \\
\hline Global & $-2.08 \%$ & 0.81 & $0.63 \%$ & 0.84 & 0.0005 \\
\hline
\end{tabular}


Table 7: Active vs. Passive Fund Performance - Full Sample Period

All funds of the merged dataset are categorized by country and investment focus. The funds of each category are further segmented into the equally weighted portfolios "Active" and "Passive" with respect to their investment style. "All Funds" portfolios include both actively and passively managed funds. Spread portfolios are created by subtracting the returns on the passive from the returns on the active portfolios. The unconditional and conditional Carhart 4-factor models are estimated over the full sample period. All standard errors are autocorrelation and Newey-West heteroskedasticity consistent. Alphas are annualized. The alpha distribution shows the percentages of alphas which are significantly negative (-), significantly positive (+) and insignificantly different from zero (0). $* / * * / * * *$ denotes significance at the $10 \% / 5 \% / 1 \%$ level.

\begin{tabular}{|c|c|c|c|c|c|c|c|c|c|c|c|}
\hline & & \multirow{2}{*}{$\begin{array}{l}\text { No. of } \\
\text { Funds }\end{array}$} & \multicolumn{7}{|c|}{ Unconditional Carhart } & \multicolumn{2}{|c|}{ Conditional Carhart } \\
\hline & & & Alpha & M & SMB & HML & MOM & $\operatorname{adj.} \mathbf{R}^{2}$ & $\alpha$ Distr. -/0/+ & Alpha & adj. $\mathbf{R}^{2}$ \\
\hline \multicolumn{12}{|l|}{ France } \\
\hline \multirow[t]{4}{*}{ Domestic } & Active & 165 & $-2.70 *$ & $0.99 * * *$ & $0.55 * * *$ & $-0.06 *$ & $-0.07 * *$ & 0.87 & $40 / 55 / 5$ & $-3.11 *$ & 0.90 \\
\hline & Passive & 26 & -3.35 & $0.93 * * *$ & $0.21 * * *$ & -0.02 & -0.06 & 0.76 & $57 / 42 / 1$ & -2.60 & 0.82 \\
\hline & All Funds & 191 & $-2.81 *$ & $0.98 * * *$ & $0.50 * * *$ & $-0.06 *$ & $-0.06 * *$ & 0.86 & $44 / 53 / 3$ & $-3.07 *$ & 0.89 \\
\hline & Spread & & 0.65 & $0.05 * *$ & $0.34 * * *$ & -0.05 & -0.01 & 0.27 & & -0.51 & 0.48 \\
\hline \multirow[t]{4}{*}{ Europe } & Active & 682 & -1.40 & $1.00 * * *$ & $0.23 * * *$ & $-0.13 * * *$ & $-0.04 *$ & 0.96 & $30 / 67 / 3$ & $-2.49 * * *$ & 0.97 \\
\hline & Passive & 41 & -2.02 & $0.86 * * *$ & 0.03 & $-0.11 *$ & $-0.10 * *$ & 0.79 & $34 / 65 / 1$ & -1.77 & 0.88 \\
\hline & All Funds & 723 & -1.44 & 0.99 **** & $0.22 * * *$ & $-0.13 * * *$ & $-0.04 *$ & 0.96 & $30 / 67 / 3$ & $-2.43 * * *$ & 0.97 \\
\hline & Spread & & 0.62 & $0.14 * * *$ & $0.21 * * *$ & -0.03 & $0.06 *$ & 0.18 & & -0.72 & 0.50 \\
\hline \multirow[t]{4}{*}{ Global } & Active & 961 & -2.93 & $0.95 * * *$ & $-0.52 * * *$ & -0.08 & 0.03 & 0.83 & $10 / 88 / 2$ & -2.17 & 0.84 \\
\hline & Passive & 55 & -1.10 & $0.77 * * *$ & 0.00 & -0.04 & -0.04 & 0.57 & $4 / 96 / 0$ & -1.53 & 0.73 \\
\hline & All Funds & 1016 & -2.89 & $0.94 * * *$ & $-0.53 * * *$ & -0.08 & 0.03 & 0.83 & 9/90/1 & -2.17 & 0.84 \\
\hline & Spread & & -1.83 & $0.17 * * *$ & -0.02 & 0.05 & $0.12 * * *$ & 0.13 & & -0.63 & 0.17 \\
\hline
\end{tabular}


Table 7 (continued): Active vs. Passive Fund Performance - Full Sample Period

\begin{tabular}{|c|c|c|c|c|c|c|c|c|c|c|c|}
\hline & & \multirow{2}{*}{$\begin{array}{l}\text { No. of } \\
\text { Funds } \\
\end{array}$} & \multicolumn{7}{|c|}{ Unconditional Carhart } & \multicolumn{2}{|c|}{ Conditional Carhart } \\
\hline & & & Alpha & $\mathbf{M}$ & SMB & HML & MOM & adj. $R^{2}$ & $\alpha$ Distr. $-/ 0 /+$ & Alpha & adj. $R^{2}$ \\
\hline \multicolumn{12}{|l|}{ Germany } \\
\hline \multirow[t]{4}{*}{ Domestic } & Active & 96 & $-3.74 * * *$ & $1.15 * * *$ & $0.13 * * *$ & -0.01 & $-0.06 * * *$ & 0.96 & $68 / 30 / 2$ & $-4.15 * * *$ & 0.96 \\
\hline & Passive & 8 & $-6.48 * * *$ & $1.21 * * *$ & -0.04 & -0.01 & $-0.08 * * *$ & 0.95 & $100 / 0 / 0$ & $-5.72 * * *$ & 0.96 \\
\hline & All Funds & 104 & $-3.95 * * *$ & $1.16 * * *$ & $0.11 * * *$ & -0.01 & $-0.06 * * *$ & 0.96 & $70 / 29 / 1$ & $-4.23 * * * *$ & 0.96 \\
\hline & Spread & & $2.74 * * * *$ & $-0.05 * * *$ & $0.17 * * *$ & -0.01 & $0.02 *$ & 0.58 & & $1.57 * *$ & 0.69 \\
\hline \multirow[t]{4}{*}{ Europe } & Active & 758 & $-1.38 *$ & $1.03 * * *$ & $0.16 * * *$ & $-0.08 * * *$ & 0.00 & 0.97 & $32 / 66 / 2$ & $-2.28 * *$ & 0.95 \\
\hline & Passive & 44 & $-1.54 *$ & $0.99 * * *$ & $-0.29 * * *$ & 0.03 & -0.01 & 0.96 & $32 / 68 / 0$ & -1.25 & 0.96 \\
\hline & All Funds & 802 & $-1.40 *$ & $1.03 * * *$ & $0.14 * * *$ & $-0.08 * * *$ & 0.00 & 0.97 & $32 / 66 / 2$ & $-2.26 * * *$ & 0.98 \\
\hline & Spread & & 0.15 & $0.04 * *$ & $0.45 * * *$ & $-0.12 * * *$ & 0.01 & 0.52 & & -1.07 & 0.61 \\
\hline \multirow[t]{4}{*}{ Global } & Active & 1375 & -2.67 & $1.00 * * *$ & $-0.55 * * *$ & $-0.09 *$ & 0.04 & 0.86 & $10 / 87 / 3$ & -1.78 & 0.86 \\
\hline & Passive & 59 & $-3.56 *$ & $0.94 * * *$ & $-0.51 * * *$ & $-0.12 * *$ & $-0.17 * * *$ & 0.79 & $5 / 95 / 0$ & -2.47 & 0.85 \\
\hline & All Funds & 1434 & -2.70 & $1.00 * * *$ & $-0.56 * * *$ & $-0.09 *$ & 0.03 & 0.86 & $10 / 88 / 2$ & -1.79 & 0.86 \\
\hline & Spread & & 0.89 & $0.06 *$ & -0.05 & 0.03 & $0.21 * * *$ & 0.18 & & 0.69 & 0.37 \\
\hline \multicolumn{12}{|l|}{ Italy } \\
\hline \multirow[t]{4}{*}{ Domestic } & Active & 95 & $3.64 * *$ & $0.75 * * *$ & $0.18 * * *$ & $-0.12 * * *$ & -0.01 & 0.89 & $22 / 64 / 14$ & -1.87 & 0.96 \\
\hline & Passive & & N/A & & & & & & & & \\
\hline & All Funds & 95 & $3.64 * *$ & $0.75 * * *$ & $0.18 * * *$ & $-0.12 * * *$ & -0.01 & 0.89 & $22 / 64 / 14$ & -1.87 & 0.96 \\
\hline & Spread & & N/A & & & & & & & & \\
\hline \multirow[t]{4}{*}{ Europe } & Active & 509 & $-2.99 * * *$ & $1.04 * * *$ & $0.17 * * *$ & $-0.07 * * *$ & 0.01 & 0.98 & $35 / 63 / 2$ & $-3.60 * * *$ & 0.98 \\
\hline & Passive & 18 & $-3.83 * *$ & $0.97 * * *$ & -0.06 & $-0.08 *$ & $-0.08 * *$ & 0.91 & $67 / 33 / 0$ & $-3.56 * *$ & 0.95 \\
\hline & All Funds & 527 & $-3.01 * * *$ & $1.04 * * *$ & $0.16 * * *$ & $-0.07 * * *$ & 0.01 & 0.98 & $39 / 60 / 1$ & $-3.60 * * * *$ & 0.98 \\
\hline & Spread & & 0.84 & $0.08 * * *$ & $0.23 * * *$ & 0.01 & $0.09 * * * *$ & 0.19 & & -0.04 & 0.45 \\
\hline \multirow[t]{4}{*}{ Global } & Active & 1050 & -2.82 & $0.96 * * *$ & $-0.50 * * *$ & -0.07 & 0.04 & 0.85 & $15 / 84 / 3$ & -2.49 & 0.86 \\
\hline & Passive & 27 & $-5.20 * * *$ & $0.85 * * *$ & $-0.68 * * *$ & $-0.09 *$ & -0.05 & 0.81 & $12 / 88 / 0$ & $-3.81 *$ & 0.81 \\
\hline & All Funds & 1077 & -2.84 & $0.96 * * *$ & $-0.50 * * *$ & -0.07 & 0.04 & 0.85 & $15 / 83 / 2$ & -2.49 & 0.86 \\
\hline & Spread & & 2.38 & $0.11 * * *$ & $0.18 * *$ & 0.03 & $0.09 * *$ & 0.09 & & 1.33 & 0.12 \\
\hline \multicolumn{12}{|l|}{ Spain } \\
\hline \multirow[t]{4}{*}{ Domestic } & Active & 80 & $-2.25 *$ & $0.87 * * *$ & 0.03 & 0.00 & $-0.06 * * *$ & 0.93 & $35 / 60 / 5$ & $-2.34 *$ & 0.95 \\
\hline & Passive & 13 & -2.36 & $1.02 * * *$ & $-0.08 *$ & 0.04 & -0.02 & 0.93 & $76 / 24 / 0$ & $-2.98 *$ & 0.95 \\
\hline & All Funds & 93 & $-2.28 *$ & 0.89 * $x^{*} *$ & 0.02 & 0.00 & $-0.06 * * *$ & 0.93 & $40 / 55 / 5$ & $-2.44 * *$ & 0.95 \\
\hline & Spread & & 0.11 & $-0.15 * * *$ & $0.11 * * *$ & $-\mathbf{0 . 0 4} * *$ & $-0.04 * * *$ & 0.63 & & 0.64 & 0.74 \\
\hline \multirow[t]{4}{*}{ Europe } & Active & 496 & $-1.53 * *$ & $1.01 * * *$ & $0.12 * * *$ & $-0.08 * * *$ & -0.01 & 0.97 & $33 / 66 / 1$ & $-2.70 * * *$ & 0.98 \\
\hline & Passive & 31 & $-1.75 *$ & $0.98 * * *$ & $-0.26 * * *$ & -0.05 & $-0.08 * * * *$ & 0.95 & $42 / 58 / 0$ & $-1.91 *$ & 0.96 \\
\hline & All Funds & 527 & $-1.57 * *$ & $1.01 * * *$ & $0.10 * * *$ & $-0.08 * * *$ & -0.01 & 0.97 & $33 / 66 / 1$ & $-2.69 * * *$ & 0.98 \\
\hline & Spread & & 0.22 & $0.03 *$ & $0.38 * * *$ & -0.03 & $0.07 * * *$ & 0.49 & & -0.80 & 0.57 \\
\hline \multirow[t]{4}{*}{ Global } & Active & 914 & -3.10 & $1.01 * * *$ & $-0.52 * * *$ & -0.08 & 0.05 & 0.83 & $11 / 88 / 1$ & -2.62 & 0.84 \\
\hline & Passive & 38 & $-4.60 * *$ & $0.91 * * *$ & $-0.40 * * *$ & $-0.15 * *$ & $-0.22 * * *$ & 0.78 & $5 / 95 / 0$ & -3.02 & 0.81 \\
\hline & All Funds & 952 & -3.14 & $1.01 * * *$ & $-0.52 * * *$ & -0.08 & 0.04 & 0.83 & $12 / 87 / 1$ & -2.65 & 0.84 \\
\hline & Spread & & 1.50 & $0.10 * * *$ & -0.12 & 0.08 & $0.26 * * *$ & 0.26 & & 0.40 & 0.35 \\
\hline \multicolumn{12}{|l|}{ UK } \\
\hline Domestic & Active & 361 & -1.38 & $0.90 * * *$ & $0.21 * * *$ & -0.03 & $-0.04 * *$ & 0.94 & $42 / 53 / 5$ & -0.93 & 0.95 \\
\hline & Passive & 34 & $-3.23 * * *$ & $0.98 * * *$ & $-0.08 * * *$ & 0.02 & 0.02 & 0.95 & $95 / 5 / 0$ & $-2.98 * * *$ & 0.95 \\
\hline & All Funds & 395 & $-1.56 *$ & $0.90 * * *$ & $0.19 * * *$ & -0.03 & $-0.04 * *$ & 0.95 & $47 / 50 / 3$ & -1.06 & 0.95 \\
\hline & Spread & & $1.85 * * *$ & $\mathbf{- 0 . 0 8} * * *$ & $0.29 * * *$ & $-0.05 * * *$ & $-0.06 * * *$ & 0.65 & & $\mathbf{2 . 0 5} * *$ & 0.67 \\
\hline Europe & Active & 364 & 0.48 & $1.06 * * *$ & $0.20 * * *$ & $-0.13 * * *$ & 0.02 & 0.91 & $20 / 75 / 5$ & -0.04 & 0.92 \\
\hline & Passive & 14 & -0.94 & $1.03 * * *$ & $-0.20 * *$ & -0.03 & -0.04 & 0.83 & $15 / 85 / 0$ & -1.03 & 0.82 \\
\hline & All Funds & 378 & 0.43 & $1.06 * * *$ & $0.19 * * *$ & $-0.12 * * *$ & 0.02 & 0.91 & $20 / 75 / 5$ & -0.08 & 0.92 \\
\hline & Spread & & 1.42 & 0.03 & $0.40 * * *$ & $-0.10 * * *$ & $0.06 * *$ & 0.40 & & 0.99 & 0.37 \\
\hline Global & Active & 918 & -1.63 & $0.97 * * *$ & $-0.43 * * *$ & -0.04 & 0.06 & 0.80 & $5 / 90 / 5$ & 1.50 & 0.84 \\
\hline & Passive & 28 & -2.87 & $0.90 * * *$ & $-0.32 * * *$ & -0.08 & $-0.10 * *$ & 0.79 & $4 / 96 / 0$ & -1.06 & 0.84 \\
\hline & All Funds & 946 & -1.68 & $0.97 * * *$ & $-0.43 * * *$ & -0.04 & 0.06 & 0.81 & $5 / 90 / 5$ & 1.42 & 0.84 \\
\hline & Spread & & 1.24 & $0.08 * * *$ & -0.11 & 0.05 & $0.17 * * *$ & 0.16 & & 2.57 & 0.23 \\
\hline
\end{tabular}


Table 8: Influence of Loads and Fees on Returns

Besides the net return dataset, two additional return datasets are generated. "Net Returns - Loads" denotes the returns net of all expenses including loads, while assuming an average fund holding period of three years. The corresponding dataset is thus constructed by subtracting $1 / 36$ of the individual funds' load charges from their monthly net returns. The dataset "Net Returns + TER" contains the funds' gross returns and is constructed by adding $1 / 12$ of the individual yearly TERs to the funds' monthly net returns. All funds of the merged dataset are categorized by country and investment focus. On the basis of these categories equally weighted portfolios are formed and three sets of portfolio returns are calculated with respect to the three return datasets. The unconditional Carhart 4-factor model is estimated over the full sample period. All standard errors are autocorrelation and Newey-West heteroskedasticity consistent. Alphas are annualized. $* / * * / * * *$ denotes significance at the $10 \% / 5 \% / 1 \%$ level.

\begin{tabular}{llccc}
\hline & & $\begin{array}{c}\text { Net Returns - Loads } \\
\text { Alpha }\end{array}$ & $\begin{array}{c}\text { Net Returns } \\
\text { Alpha }\end{array}$ & $\begin{array}{c}\text { Gross Returns } \\
\text { Alpha }\end{array}$ \\
\hline France & Domestic & $-3.84 * *$ & -2.72 & -1.06 \\
& Europe & $-3.02 * * *$ & -1.52 & 0.11 \\
& Global & $-4.47 * *$ & -2.91 & -1.13 \\
Germany & Domestic & $-4.48 * * *$ & $-3.91 * * *$ & $-2.56 *$ \\
& Europe & $-2.13 * * *$ & $-1.37 *$ & 0.26 \\
& Global & $-3.47 *$ & -2.69 & -0.91 \\
& & & & $5.57 * * *$ \\
Staly & Domestic & 2.42 & $3.64 * *$ & 0.45 \\
& Europe & $-3.12 * * *$ & $-1.41 *$ & -0.90 \\
& Global & $-4.46 * * *$ & $-2.86 *$ & 2.20 \\
& & & & 0.17 \\
& Domestic & -0.23 & 0.16 & -1.20 \\
& Europe & $-3.23 * * *$ & $-1.69 * *$ & 0.00 \\
& Global & $-4.81 * *$ & -3.16 & 3.30 \\
& Domestic & $-2.71 * * *$ & -1.39 & 0.59 \\
\hline
\end{tabular}


Table 9: Cross- Sectional Analysis

For all funds of the merged dataset being active during 2004 individual unconditional Carhart 4-factor alphas are estimated. Models (5) (6) and (7) are estimated in order to regress the individual alphas against the respective fund's cross-sectional characteristics.

$* / * * / * * *$ denotes significance at the $10 \% / 5 \% / 1 \%$ level.

\begin{tabular}{|c|c|c|c|c|c|c|}
\hline \multirow[b]{2}{*}{ Variable } & \multicolumn{2}{|c|}{ Model (5) } & \multicolumn{2}{|c|}{ Model (6) } & \multicolumn{2}{|c|}{ Model (7) } \\
\hline & Coefficient & t-Statistic & Coefficient & t-Statistic & Coefficient & t-Statistic \\
\hline $\mathrm{C}$ & $-10.95 * * *$ & -10.42 & $-11.69 * * *$ & -12.22 & $-11.05 * * *$ & -11.70 \\
\hline Bank & $-0.28 *$ & -1.78 & $-0.36 * *$ & -2.41 & $-0.27 *$ & -1.80 \\
\hline Active & $0.98 * * *$ & 2.96 & $0.69 * *$ & 2.33 & $0.75 * * *$ & 2.63 \\
\hline Retail & -0.44 & -1.01 & -0.40 & -0.92 & -0.43 & -0.98 \\
\hline LN Age & 0.21 & 1.59 & 0.15 & 1.26 & 0.11 & 0.95 \\
\hline Ln Assets & $0.41 * * *$ & 9.06 & $0.45 * * *$ & 10.43 & $0.42 * * *$ & 9.80 \\
\hline TSC & -0.12 & -0.74 & & & & \\
\hline TER & & & -0.14 & -0.67 & & \\
\hline Administration & & & & & $1.04 *$ & 1.85 \\
\hline Management & & & & & -0.23 & -1.14 \\
\hline Audit & & & & & -5.73 & -1.44 \\
\hline Subsidy & & & & & 0.03 & 0.32 \\
\hline Custody & & & & & 0.05 & 0.18 \\
\hline Distribution & & & & & 0.39 & 0.53 \\
\hline Performance & & & & & 0.32 & 1.28 \\
\hline Other & & & & & $-0.63 *$ & -1.66 \\
\hline Initial & & & 0.22 & 1.00 & 0.18 & 0.80 \\
\hline Redemption & & & 0.09 & 0.54 & 0.07 & 0.43 \\
\hline Dummy Germany & -0.19 & -0.45 & 0.04 & 0.20 & 0.09 & 0.39 \\
\hline Dummy Italy & -0.30 & -0.71 & -0.06 & -0.26 & -0.04 & -0.18 \\
\hline Dummy Spain & -0.43 & -0.69 & -0.09 & -0.17 & -0.13 & -0.25 \\
\hline Dummy UK & $1.13 * *$ & 2.36 & $1.43 * * *$ & 4.41 & $1.51 * * *$ & 4.37 \\
\hline Dummy Europe & $0.77 * *$ & 1.96 & $0.75 * *$ & 2.18 & $0.69 * *$ & 2.07 \\
\hline Dummy Global & $1.28 * * *$ & 3.32 & $1.32 * * *$ & 3.85 & $1.26 * * *$ & 3.84 \\
\hline $\operatorname{adj.} R^{2}$ & $\mathbf{0 . 0 3}$ & & 0.04 & & 0.04 & \\
\hline
\end{tabular}


Table 10 6, 12 and 36 Month Horizon Performance Persistence - Full Time Period Spread Portfolios

All funds of the time series dataset are categorized by country and investment focus. For each category, at the beginning of January 1993 (January 1995) ten equally weighted decile portfolios are formed on the basis of the prior 12 (36) month excess returns. Portfolio 1 contains the funds with the highest and portfolio 10 the funds with the lowest past excess returns. Based on the same measure the top and bottom portfolios of the 12 month horizon ranking are further subdivided into tertile sub-portfolios. Spread portfolios are formed by subtracting the returns on portfolio 10 (10C) from portfolio 1 (1A). (Sub-)Portfolios are held over the horizon of 12 (36) months and then re-formed with the same methodology, yielding a time series of monthly returns for each (sub)portfolio. The unconditional Carhart 4-factor model is estimated over the full time period. All standard errors are autocorrelation and Newey-West heteroskedasticity consistent. Alphas are annualized. Only the excess returns and alpha estimates of the spread portfolios are displayed below. For comparison the corresponding alpha and excess return estimates for the 6 month horizon analysis are reported as well.

$* / * * / * * *$ denotes significance at the $10 \% / 5 \% / 1 \%$ level.

\begin{tabular}{|c|c|c|c|c|c|c|}
\hline & \multicolumn{2}{|c|}{6 Month } & \multicolumn{2}{|c|}{12 Month } & \multicolumn{2}{|c|}{36 Month } \\
\hline & $\begin{array}{l}\text { Excess } \\
\text { Return } \\
\end{array}$ & Alpha & $\begin{array}{l}\text { Excess } \\
\text { Return } \\
\end{array}$ & Alpha & $\begin{array}{l}\text { Excess } \\
\text { Return } \\
\end{array}$ & Alpha \\
\hline \multicolumn{7}{|l|}{ France } \\
\hline Domestic 1 - 10 & 10.73 & $12.27 * * *$ & 7.29 & $7.96 * *$ & 2.96 & 3.50 \\
\hline Domestic 1A - 10C & 17.09 & $19.76 * * *$ & 11.44 & $12.24 * * *$ & & \\
\hline Europe 1 - 10 & 11.02 & $12.01 * * *$ & 5.77 & $4.75 *$ & 2.80 & 1.55 \\
\hline Europe $1 \mathrm{~A}-10 \mathrm{C}$ & 15.31 & $16.78 * * *$ & 10.29 & $9.49 * *$ & & \\
\hline Global 1 - 10 & 7.96 & 5.76 & 10.20 & $7.40 *$ & 0.06 & -1.83 \\
\hline Global 1A - 10C & 13.36 & $10.92 *$ & 11.92 & $9.57 *$ & & \\
\hline \multicolumn{7}{|l|}{ Germany } \\
\hline Domestic 1 - 10 & 10.37 & $10.81 * * *$ & 10.53 & $10.72 * * *$ & 7.47 & $7.60 * * *$ \\
\hline Domestic $1 \mathrm{~A}-10 \mathrm{C}$ & 10.39 & $10.25 * *$ & 16.29 & $15.81 * * *$ & & \\
\hline Europe 1 - 10 & 12.38 & $14.05 * * *$ & 6.17 & $6.00 * *$ & 0.93 & 0.92 \\
\hline Europe $1 \mathrm{~A}-10 \mathrm{C}$ & 19.29 & $20.61 * * *$ & 10.27 & $10.18 * *$ & & \\
\hline Global 1 - 10 & 8.24 & 6.63 & 9.35 & $6.72 *$ & -0.83 & -2.80 \\
\hline Global 1A - 10C & 14.09 & $12.56 *$ & 11.30 & $9.21 *$ & & \\
\hline \multicolumn{7}{|l|}{ Italy } \\
\hline Domestic 1 - 10 & 7.41 & $7.83 * * *$ & 4.75 & $5.05 * * *$ & 3.21 & $3.09 * * *$ \\
\hline Domestic $1 \mathrm{~A}-10 \mathrm{C}$ & 11.64 & $11.39 * * *$ & 8.65 & $7.86 * * *$ & & \\
\hline Europe 1 - 10 & 12.56 & $13.82 * * *$ & 4.60 & 4.13 & -2.13 & -2.85 \\
\hline Europe $1 \mathrm{~A}-10 \mathrm{C}$ & 15.00 & $15.68 * * *$ & 4.11 & 4.14 & & \\
\hline Global 1 - 10 & 7.37 & 5.52 & 8.62 & $6.27 *$ & -1.71 & -3.28 \\
\hline Global 1A - 10C & 11.78 & 9.91 & 10.65 & $8.38 *$ & & \\
\hline \multicolumn{7}{|l|}{ Spain } \\
\hline Domestic 1 - 10 & 5.82 & 4.73 & 5.37 & 3.81 & 5.10 & $4.39 *$ \\
\hline Domestic $1 \mathrm{~A}-10 \mathrm{C}$ & 3.35 & 2.12 & 1.75 & 1.67 & & \\
\hline Europe 1 - 10 & 12.56 & $13.90 * * *$ & 4.60 & 4.15 & 0.66 & -0.64 \\
\hline Europe $1 \mathrm{~A}-10 \mathrm{C}$ & 15.74 & $16.34 * * *$ & 7.77 & 6.03 & & \\
\hline Global 1 - 10 & 9.80 & 7.59 & 9.55 & 6.20 & -0.24 & -1.97 \\
\hline Global 1A - 10C & 13.09 & $11.83 *$ & 10.95 & 7.89 & & \\
\hline \multicolumn{7}{|l|}{$U K$} \\
\hline Domestic 1 - 10 & 11.47 & $11.85 * * *$ & 7.65 & $8.84 * * *$ & 1.72 & 2.16 \\
\hline Domestic $1 \mathrm{~A}-10 \mathrm{C}$ & 18.73 & $19.80 * * *$ & 13.78 & $16.28 * * *$ & & \\
\hline Europe 1 - 10 & 11.69 & $12.46 * * *$ & 5.64 & $6.45 * *$ & 2.72 & 1.17 \\
\hline Europe $1 \mathrm{~A}-10 \mathrm{C}$ & 14.68 & $16.16 * * *$ & 9.89 & $11.08 * *$ & & \\
\hline Global 1 - 10 & 7.61 & 7.15 & 9.74 & $8.59 * *$ & -2.45 & -3.62 \\
\hline Global 1A - 10C & 14.10 & $14.49 * *$ & 10.68 & $10.31 * *$ & & \\
\hline
\end{tabular}

